\title{
Review
}

\section{Mini-Review: Recent Technologies of Electrode and System in the Enzymatic Biofuel Cell (EBFC)}

\author{
Nabila A. Karim ${ }^{1, *(D)}$ and Hsiharng Yang ${ }^{2,3, *(D)}$ \\ 1 Fuel Cell Institute, Universiti Kebangsaan Malaysia, Bangi 43600, Selangor, Malaysia \\ 2 Graduate Institute of Precision Engineering, National Chung Hsing University, 145 Xingda Road, South \\ District, Taichung City 402, Taiwan \\ 3 Innovation and Development Center of Sustainable Agriculture (IDCSA), National Chung Hsing University, \\ 145 Xingda Road, South District, Taichung City 402, Taiwan \\ * Correspondence: nabila.akarim@ukm.edu.my (N.A.K.); hsiharng@dragon.nchu.edu.tw (H.Y.)
}

Citation: A. Karim, N.; Yang, H.

Mini-Review: Recent Technologies of Electrode and System in the

Enzymatic Biofuel Cell (EBFC). Appl. Sci. 2021, 11, 5197. https://doi.org/ 10.3390/app11115197

Academic Editor: José Machado

Received: 30 April 2021

Accepted: 1 June 2021

Published: 3 June 2021

Publisher's Note: MDPI stays neutral with regard to jurisdictional claims in published maps and institutional affiliations.

Copyright: (c) 2021 by the authors. Licensee MDPI, Basel, Switzerland. This article is an open access article distributed under the terms and conditions of the Creative Commons Attribution (CC BY) license (https:/ / creativecommons.org/licenses/by/ $4.0 /)$.

\begin{abstract}
Enzymatic biofuel cells (EBFCs) is one of the branches of fuel cells that can provide high potential for various applications. However, EBFC has challenges in improving the performance power output. Exploring electrode materials is one way to increase enzyme utilization and lead to a high conversion rate so that efficient enzyme loading on the electrode surface can function correctly. This paper briefly presents recent technologies developed to improve bio-catalytic properties, biocompatibility, biodegradability, implantability, and mechanical flexibility in EBFCs. Among the combinations of materials that can be studied and are interesting because of their properties, there are various nanoparticles, carbon-based materials, and conductive polymers; all three have the advantages of chemical stability and enhanced electron transfer. The methods to immobilize enzymes, and support and substrate issues are also covered in this paper. In addition, the EBFC system is also explored and developed as suitable for applications such as self-pumping and microfluidic EBFC.
\end{abstract}

Keywords: electrode; support; immobilization; enzyme; EBFC

\section{Introduction}

Enzymatic biofuel cells (EBFCs) is one of the branches of biofuel cells, other than microbial fuel cells (MFCs), that constitutes one of the emerging areas of green energy and nanotechnology [1] to reduce carbon dioxide emissions [2]. EBFC is easily applied and provides power [3] in implantable medical devices such as cardiac pacemakers [4], drug delivery [5], implantable artificial organs [6], and wastewater treatment [7]. The EBFC is also used as a biosensor for biomolecules detection, such as toxic pollutants [8] and glucose detection [9]. Detection of toxic pollutants can protect the environment from being exposed to the danger of molecule release at low concentrations [10]. In addition, the use of EBFC in medical devices is seen to bring advantages due to the small size of the EBFC [11], its flexibility, light weight, and easy portability [12], and more importantly, its sufficient usage at low power [13]. Making EBFCs for various uses is simple and low cost compared to other types of fuel cells. Each fuel cell has a lifetime and has its way of disposal. In contrast, EBFC, which has a small size, is accessible to disposal [14]. The EBFC operating process is also easy, rapid to start-up, eco-friendly, has an anti-interference performance [3], and is easy to operate at room temperature and neutral $\mathrm{pH}[15,16]$.

Despite having many advantages, EBFC also has its challenges, where there is still room for improvement to increase the potential usage of EBFC. Combining various substances with enzymes carries the challenges of biocatalytic properties, biocompatibility, biodegradability, implantability, and mechanical flexibility in EBFC [17]. The shortcoming in the EBFC system leads to integrated miniaturization issues [18], lower power density, poor operational stability, lower voltage output [19], lower energy density, inadequate durability, instability in long-term application [15,20], and incomplete oxidation of fuel [21]. 
Various non-toxic chemical fuels are used in EBFC, such as glucose, lactate, urate, alcohol, amines, starch, and fructose [22], and have a specific enzyme to oxide these fuels; for example, the cellobiose dehydrogenase is used to oxide the lactose in the EBFC [23]. However, glucose is widely used because it has the advantages of being abundant, easy to obtain, cheap [24], and involved in various functions [25]. An enzyme is used in EBFC as a catalyst. In the anode, the enzyme commonly oxidizes the glucose into gluconolactone and produces electrons and protons. Glucose oxidase is widely used because it has advantages such as availability [26], high selectivity [27], and high catalytic activity to oxide glucose [25], self-discharge, low mix potential [28], and ease of use in a membrane-less EBFC system. At the same time, the enzyme at the cathode will complete the reduction reaction by using electrons and protons from the anode and then generate electricity. The working principle in EFC at the anode and cathode is given below:

Complete oxidation of glucose:

$$
\mathrm{C}_{6} \mathrm{H}_{12} \mathrm{O}_{6}+6 \mathrm{O}_{2} \rightarrow 6 \mathrm{CO}_{2}+6 \mathrm{H}_{2} \mathrm{O}
$$

Anodic glucose oxidation (GOx):

$$
\mathrm{C}_{6} \mathrm{H}_{12} \mathrm{O}_{6} \stackrel{\mathrm{GOx}}{\rightarrow} \mathrm{C}_{6} \mathrm{H}_{10} \mathrm{O}_{6}+2 \mathrm{e}^{-}+2 \mathrm{H}^{+}
$$

Cathodic oxygen reduction (laccase):

$$
\frac{1}{2} \mathrm{O}_{2}+2 \mathrm{H}^{+}+2 \mathrm{e}^{-} \rightarrow \mathrm{H}_{2} \mathrm{O}
$$

Total:

$$
\mathrm{C}_{6} \mathrm{H}_{12} \mathrm{O}_{6}+\frac{1}{2} \mathrm{O}_{2} \rightarrow \mathrm{C}_{6} \mathrm{H}_{10} \mathrm{O}_{6}+\mathrm{H}_{2} \mathrm{O}
$$

\section{The Enzyme, Support, and Substrate in EBFC}

Enzymes are placed or immobilized on the surface of support materials, and the efficient immobilization of the enzyme is challenging. There are various ways to immobilize the enzyme on the electrode surface, such as encapsulation [3], physical adsorption, entrapment in conduction polymer [29], crosslinking [30], layer-by-layer assembly [31], and covalent attachment [32], in which the enzyme can be reusable, cost-effective, and recyclable [33]. For more understanding, the reader can view the technologies of immobilization from this reference [34]. Figure 1 shows the differences in physical adsorption, covalent attachment, and encapsulation of the enzyme immobilization [35]. The activity and stability of immobilized enzymes depend on the conditions and microenvironment in which enzyme molecules are confined [36]. Not only that, the materials to be used to immobilize the enzyme need to consider the hardness and electrical conductivity of the materials [33]. A novel approach by Sakthivel et al. [37] used the defect and dislocation of nickel-doped $\mathrm{MoSe}_{2}$ nanoplates for enzyme entrapment for both the bioanode and biocathode. In contrast, Shakeel et al. [21] used the interaction between $\mathrm{NiMoSe}_{2}$ nanoplates and a polypyrrole matrix-single walled carbon nanotube to immobilize the biomolecules. The use of $2 \mathrm{D} \mathrm{NiMoSe}{ }_{2}$, which has a high defect, can help increase enzyme loading and entrap the enzyme, and CNT and polypyrrole help conductivity on the electrode surface. The excellent performance and reversibility in using this material have produced high-speed kinetics with a value of $15.6 \mathrm{~s}^{-1}$.

A convenient immobilization method recommended for interaction between enzyme and support [30] needs to increase the enzyme's storage, solvent, $\mathrm{pH}$, and thermal stability $[3,33,38]$. However, some factors have been detected behind enzyme-support interactions that lead to low power and energy density. There is the inadequate and inefficient interaction [16] as well as imperfect [20] and low enzyme loading between enzyme and support that reduces electron transfer [39], leaches out enzyme [26], leads to degradation in long-term operation, causes potential enzyme poisoning when using non-biocompatibility 
support materials, reduced lifetime [21], and limited enzyme stability [24,39]. Various materials and methods are used to alleviate this problem that give different chemical, mechanical, and electrical properties [39,40]; for example, Ji et al. [41] reduced the leached out enzyme problem by linking the interaction between hemin and carbon nanotubes through functionalized amine groups to form amide bonds, as shown in Figure 2. Meanwhile, they conjugated the GOx enzyme with two poly (dimethyl-diallyl ammonium chloride), producing a sandwich structure, which maintains GOx loading. The stability of this chemical bonding has kept $82.1 \%$ activity for four weeks. Figure 2 also shows that various interaction experiments produce different electrochemical reaction activities. In addition to covalent bonds formed through the amino group, crosslinking agents are also possible through carboxyl (-COOH) groups [42]. Ji et al. [43] produced polyethyleneimine (PEI), in which the redox polymer is used to entrap and bind GOx enzyme with F-N/CNT and PEI, thus making physical interaction through electrostatic attraction. PEI offers advantages in increasing electron transfer because it has a lower glass transition that mobilizes between the polymer structures and has high stability, sensitivity [42], and conductivity [16]. In addition, US et al. [18] minimized enzyme leaching by producing laser-induced graphene with CNTs in microfluidic EBFCs. The high porosity and low cost of this material increase the active site for the enzyme and give 1.37 times higher power density than without CNTs.
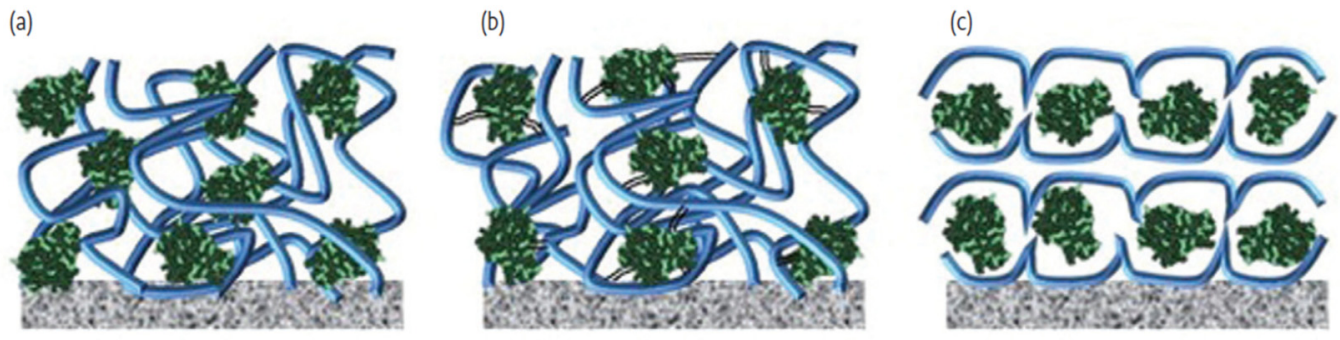

Figure 1. Enzymes immobilized on an electrode surface via (a) physical adsorption to a polymer, (b) covalent attachment to a polymer (as shown by the black and white tethers), or (c) encapsulation in [35]. Copyright 2012 Elsevier.

Shakeel et al. [1] produced carbon composites by combining MWCNT with Kraton (non-perfluorinated sulfonated penta block copolymer) to form an excellent matrix for enzyme immobilization. Kraton has high ion mobility, film-forming ability, and high proton conductivity that can produce a current as high as $1.14 \mathrm{~mA} / \mathrm{cm}^{2}$ at a glucose concentration of $60 \mathrm{mM}$. Kang et al. [39] developed a rectangular carbon tube with a concave surface to immobilize the GOx and laccase (LAC) from rectangular polypyrrole (RPPy). RPPy is carbonized at high temperatures so that the resulting surface structure has defects at a high degree of disorder and low degree of intralayer binding of the amorphous carbon. In addition, Arjun et al. [2] used pyrene carboxylic acid with MWCNT and reduced graphene oxide-ceria for the electrostatic immobilization of enzymes via calcium ions. The calcium ion is produced on the electrode surface by dipping the electrode in a calcium chloride solution for two hours.

The electrode consists of a substrate and support material. The support material is used to support the enzyme and will be on the surface of the substrate. The commonly used substrate is carbon cloth [44], carbon paper [45], indium tin oxide (ITO) [22], glassy carbon electrode [46], and buckypaper [47], because these carbon-based materials provide advantages such as high compatibility, being user-friendly, and being environmentally friendly and made of reusable material [40], through physical adsorption or chemical bonding to form the carbon composites [39]. Substrates are rarely studied in EBFCs, but Shen et al. [48], using graphene paper [49], used the reduction method followed by crosslinking to strengthen the mechanical stability of the material and used it for the anode and cathode in the EBFC, as shown in Figure 3. In the EBFC system developed, authors use pyrroloquinoline-dependent glucose dehydrogenation (PGG-GDH) and bilirubin oxidase $(\mathrm{BOx})$ as the enzyme anode and cathode. Wan et al. [50] used carbon paper to solve the 
problem of the low solubility of the gas molecule in the aqueous solution with polytetrafluoroethylene to increase its hydrophobicity. Low power due to low oxygen solubility was increased by producing power of $53.0 \mu \mathrm{W} / \mathrm{cm}^{2}$ at $0.45 \mathrm{~V}$. Rewatkar et al. [51] applied the buckypaper as a bioelectrode for both GOx and laccase at the bioanode and biocathode without a redox co-factor, which offers various advantages, such as highly efficient electron transfer, scalable production, high electrical conductivity, and large specific areas [52], respectively. Niiyama et al. [44] modified the carbon cloth with MgO-template porous carbon to further increase the electrochemically active surface area on the electrode surfaces. Both modified electrodes use an anodic and cathode binder, namely poly(vinylidenedifluoride) and polytetrafluoroethylene. The authors modified the carbon cloth using an $\mathrm{MgO}$ template to form mesoporous carbon and were able to control the pore size distribution to immobilize the enzyme.
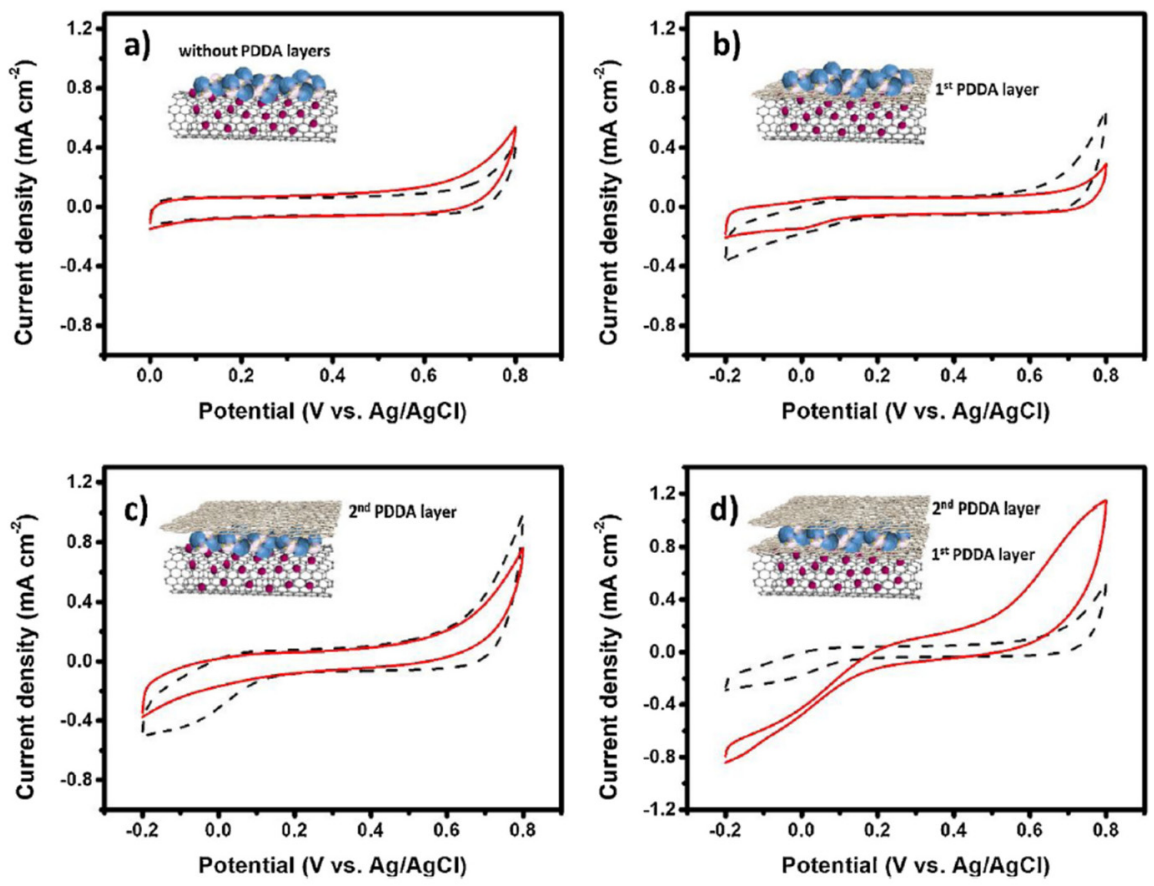

Figure 2. CV curves of catalysts using amine-CNT/hemin, PDDA layers and GOx. (a) (AmineCNT/hemin)/GOx, (b) (amine-CNT/hemin)/PDDA/GOx, (c) (amine-CNT/hemin)/GOx/PDDA, and (d) (amine-CNT/hemin)/PDDA/GOx/PDDA, without the injection of glucose (black dashed line) and with the injection of $30 \mathrm{mM}$ glucose (red solid line). For the tests, $0.01 \mathrm{M}$ PBS (pH 7.4) was used as an electrolyte under air condition [41]. Copyright 2020 Elsevier.

The enzyme will attach to the surface of the support material, where the oxidation and decomposition reactions take place to produce current or power. However, it should be noted that enzymes will oxidize and reduce, such as in Equations (2) and (3), and the resulting electrons need to flow to the electrode. There are two ways of electron transfer in EBFC, namely mediated electron transfer (MET) and direct electron transfer (DET) [22]. The redox mediator is used in MET as an electron acceptor for electron transfer. These mediators are encouraged to attach at the electrode [28] to increase electron transfer by covalently attaching to a polymer backbone or directly adsorbing on the electrode surface by weak noncovalent immobilization or physical adsorption by drop-casting; both methods still carry the problem of mediator leaching. Tsuruoka et al. [53] investigate various mediators, namely, polymerized phenothiazines (thionine, methylene green, methylene blue, and toluidine blue). Among the mediators, the poly(methylene green) shows a clear redoxmediating ability with a current density of $3 \mathrm{~mA} / \mathrm{cm}^{2}$. The current produced depends on the concentration of enzyme and glucose and the polymer loading on the electrode surface. The use of MET was detected to have problems such as toxicity of the mediator, leakage, 
producing a low open-circuit voltage (OCV), mediator mobilization [1], being expensive, and instability of the metal ion-based redox [43], even though using MET can produce higher EBFC power than DET [15]. The production of mediators for the interaction between the enzyme and the electrode surface needs to consider the same structure between the mediator and the co-factor and add a polymerizable vinyl group to the mediator if using a mediator-containing polymeric network [54]. Korkut et al. [55] synthesized a mediatormodified working electrode through poly(methyl methacrylate-co-vinyl ferrocene) by free radical polymerization. The mediator-modified electrode showed good electrochemical reaction by the GOx and $\mathrm{BOD}$ for the glucose oxidation and oxygen reduction reactions, respectively, by optimizing the cell parameters such as polymer amount, temperature, and cell voltage EBFC.

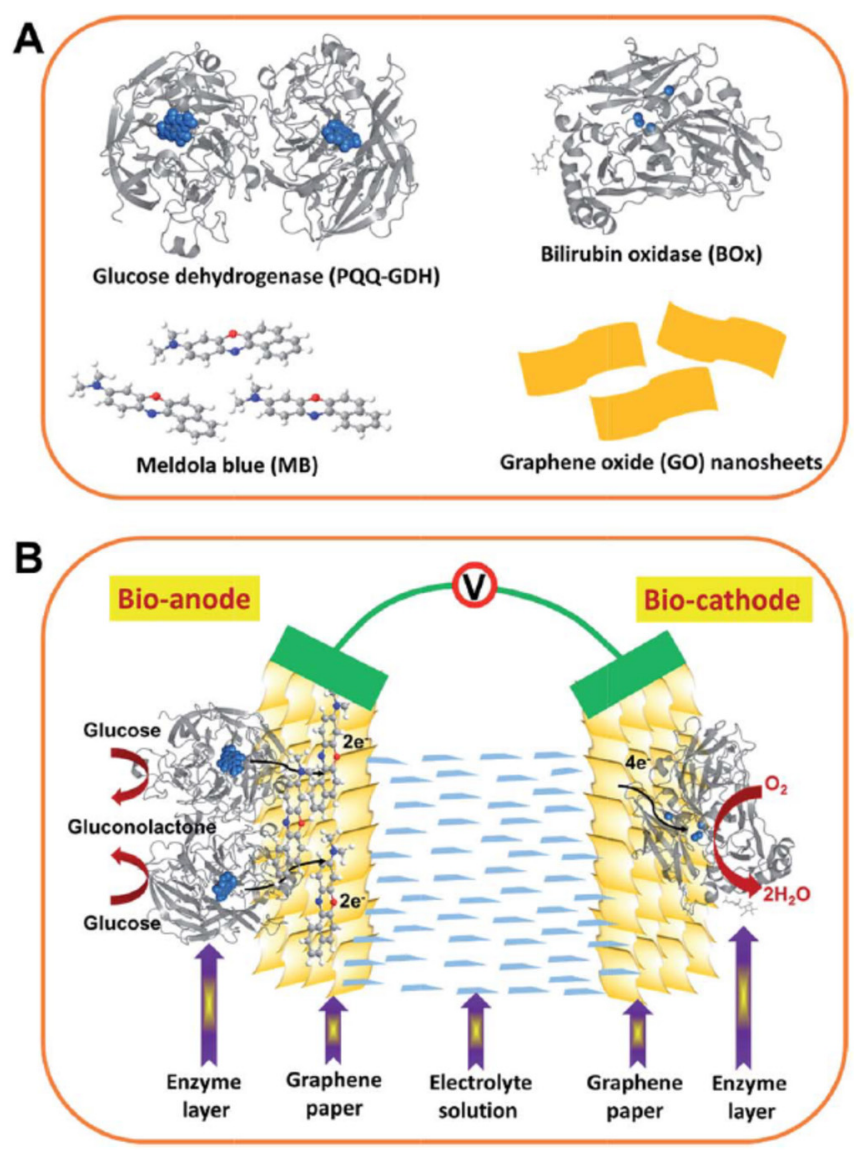

Figure 3. Schematic illustration of (A) the structures of the main building block materials and (B) the assembled enzymatic biofuel cell [48]. Copyright 2019 Royal Society of Chemistry.

The DET is when electrons are transferred directly from enzymes to conductive supports on electrodes [46]. The electrode is the direct redox acceptor. However, the barrier leading to low DET is that the redox center found in the enzyme is located deeply in 3D protein matrices $[15,28]$. Among the ways to increase electron transfer through MET and DET is to use small molecules of the active mediators and develop highly conductive materials with a high active site for enzyme loading, respectively [56]. Herkendell et al. [57] created a double layer of carbon electrode in which the mesoporous carbon nanoparticle and carbon-coated magnetic nanoparticle, referring to the first and second layers of carbon electrode, activated both MET and DET, respectively. The carbon-coated magnetic nanoparticle forms the immobilized enzyme through cascade formation, as shown in Figure 4. Herkendell et al. [58] produced Fe-based nanoparticles (diameter of the nanoparticle was $25 \mathrm{~nm}$ ) and coated them on the carbon layer to trigger the DET transfer to reduce the leakage issues and prevent the destructive enzyme modification paths. Fe-based nanoparticles 
with a magnetic field gradient feature help the DET process from enzyme to electrode surface while increasing the lifetime of the EBFC. However, some studies use an additive or adhesive agent to help electron transfer, such as Nafion [33,59], n-type semiconductor polymer [25], and ferritin (Frt) [15].

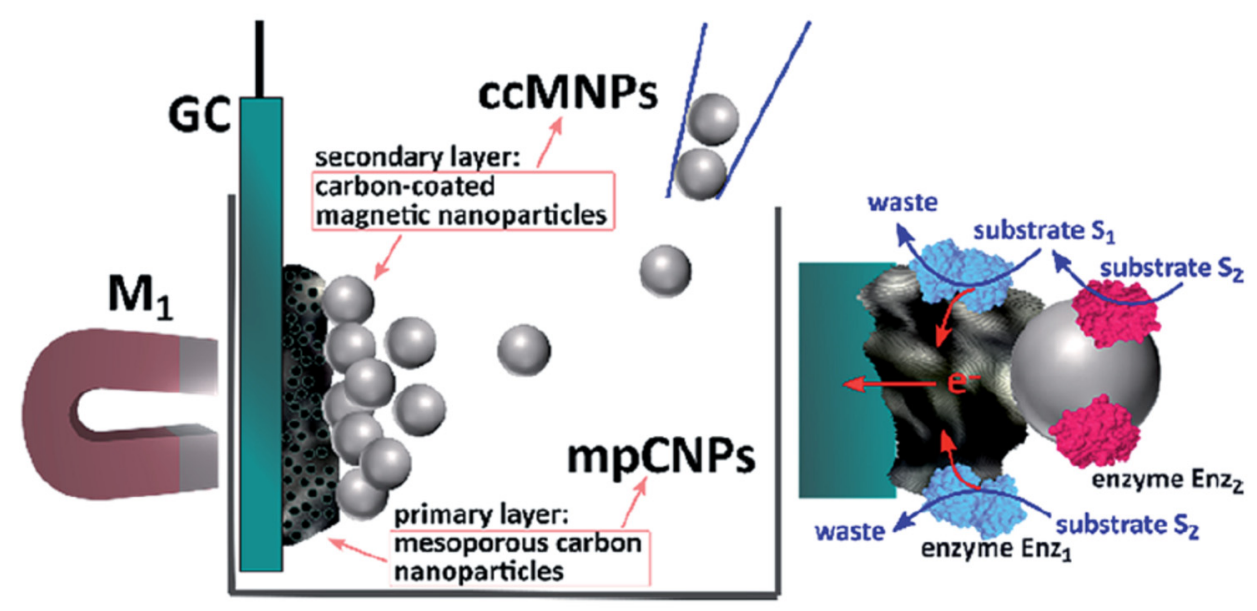

Figure 4. Illustration of the magnetic activation of bioelectrocatalytic cascades through channeling of enzyme-modified magnetic nanoparticles onto the surfaces of enzyme-functionalized mesoporous carbon nanoparticles [57]. Copyright 2019 Royal Society of Chemistry.

Electrodes need to have specific characteristics so that the enzyme can be fully utilized. To achieve biocompatibility and biodegradability between enzyme and electrode in EBFC, the electrode used must have low toxicity or chemical inertness and high reproducibility. High surface activity with a large surface-to-volume ratio is required so that the electrode in EBFC can achieve high energy conversion efficiency [35]. The selection of materials for electrodes requires abundance, low cost [20], ease to produce, and scalability, so that the manufacturing and commercialization process becomes easy. The essential criteria for electrode development are a robust adsorption site [14] for enzyme and mediator interaction on the support and support-substrate interaction. The result of a strong interaction between enzyme and support, mediator and support, and support and substrate reduces overpotential, and gives high durability and stability in long-term operation.

The development of suitable and robust interaction on the support material is needed to reduce the problems encountered in the enzyme immobilization process. Good support material with a high surface area and low aggregation can provide many sites for enzyme immobilization. Not only that, the mesoporous support material will help mass transport to the enzyme and increase the electronic double layer. Producing mesostructured support material needs to look at controlling uniform pore structure and pore size because the random size will cause underutilization of the support materials [60]. Development of new support materials needs to explore some of these factors to improve the ability to use supports in EBFC, namely electron transfer rate resulting from enzyme-support/electrode interaction [12], enzyme thickness, enzyme loading [15], enzyme conformation, and interfacial stability of the enzyme-support/electrode [3].

\section{Current Development on the Bioanode and Biocathode in EBFC}

A strong interaction between support materials and enzymes is needed to strengthen the enzyme's immobilization and reduce enzyme leaching. A study from Miki et al. [32] showed that the resulting covalent bond of a nitrophenyl group on the surface of a modified graphene support strengthens interaction with enzyme, which helps the DET process between the graphene support and enzyme. Meanwhile, the study from Innamuddin et al. [61] modified the CNT surface by functionalizing it with polyindole and $\mathrm{ZnO}$ to form an interaction support with enzyme and ferritin as a mediator. A high current density of $4.9 \mathrm{~mA} / \mathrm{cm}^{2}$ produced after consuming $50 \mathrm{mM}$ glucose concentration proves an electron 
transfer that applies efficiently. The same group's research using nickel oxide and silver nanowires showed a higher current density of 5.4 [16] and $19.9 \mathrm{~mA} / \mathrm{cm}^{2}$ [56]. Investigations that use CNT as support material have been carried out widely in EBFC. For example, Sakamoto et al. [62] investigated pyrene(NHS) and $\mathrm{Ni}^{2+}-\mathrm{NTA}$ as a binder of the enzyme on the CNT surface for the bioanode and biocathode. Kang et al. [39] developed a carbon tube by carbonizing rectangular polypyrrole for both the electrode bioanode and biocathode. Temperature changes cause the rectangular structure to change slightly, as shown in Figure 5. The unique morphology of the carbon tube offers a high power density of $0.350 \mathrm{~mW} / \mathrm{cm}^{2}$ and $0.265 \mathrm{~mW} / \mathrm{mg}$ (GOx). An exciting study from Tominaga et al. [14] used MWCNT as a support and cellulose nanofiber sheet as the electrode in EBFC. After combining the bioanode and biocathode, the very thin electrode makes it easier to dispose of but gives a high power, as high as $27 \mu \mathrm{W} / \mathrm{cm}^{2}$.

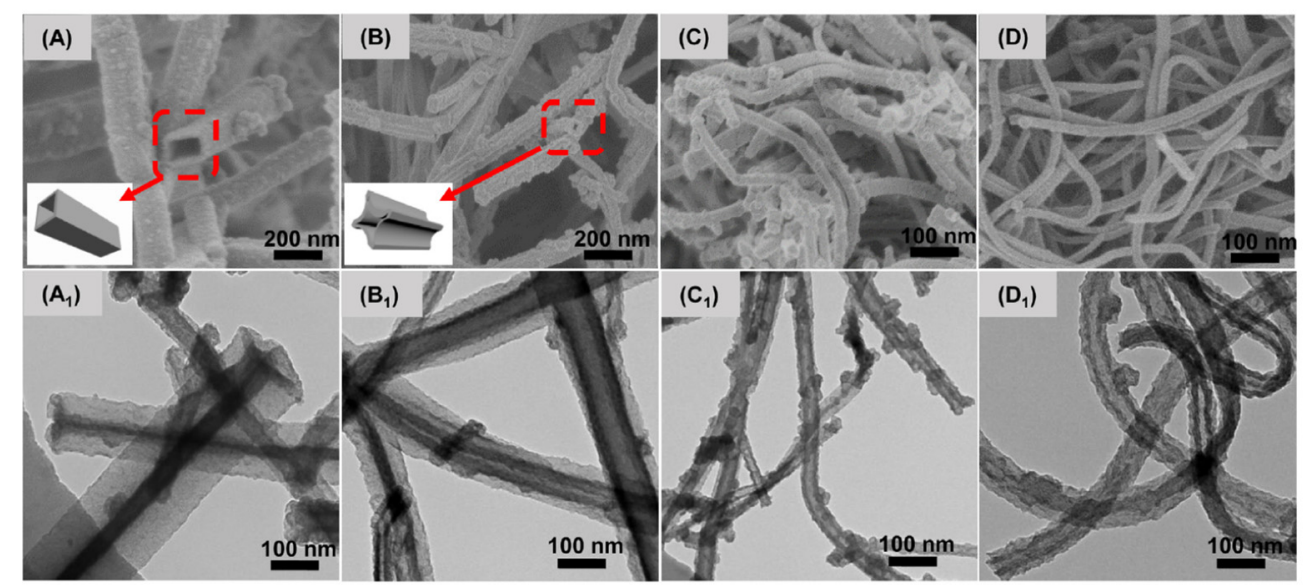

Figure 5. Characterization of the RPPy and CPPy before and after being carbonized at $1600{ }^{\circ} \mathrm{C}$. SEM images of (A) RPPy, (B) RPPy1600, (C) CPPy, and (D) CPPy1600; TEM images of (A 1 ) RPPy, (B) RPPy1600, (C $\mathbf{1})$ CPPy, and (D1) CPPy1600 [39]. Copyright 2019 Elsevier.

To reduce the leaching and optimize GOx on the electrode surface, Hyun et al. [28] developed the crosslink with chitosan and genipin as support materials, and with nitrobenzoic acid as a new mediator attached to the electrode by chemical bonding. The authors also modified the surface chitosan by distributing the abundant functional evenly on the chitosan surface structure to help covalently bond the GOx and mediator. Analysis showed that the enzyme loading on the electrode surface reached $17.8 \mathrm{mg} / \mathrm{mL}$ and produced a current as high as $331 \mu \mathrm{A} / \mathrm{cm}^{2}$ at $0.3 \mathrm{~V}$ vs. $\mathrm{Ag} / \mathrm{AgCl}$ and low onset potential $(0.05 \mathrm{~V}$ vs. $\mathrm{Ag} / \mathrm{AgCl}$ ). Duong et al. [16] directly modified the carbon cloth (CC) substrate with chitosan, commonly used as a biosensor and in biomedical applications, to support glucose oxidase enzyme. The additive assists electron transfer at the electrode, and the modification of the chitosan over the CC requires appropriate additive testing. In this study, sodium tripolyphosphate (TPP) and Nafion were selected as additives, but the results show good electron transfer using TPP. The biocompatibility of the genipin used in EBFCs is because it has lower cytotoxicity and is highly efficient to crosslink between chitosan, glucose oxidase, and the amine-containing osmium redox complex developed by Conghaile et al. [30]. The authors also increased the current density by adding multi-walled carbon nanotubes on the electrode as high as $4.9 \mathrm{~mA} / \mathrm{cm}^{2}$, higher than the previous, which produced only $440 \mu \mathrm{A} / \mathrm{cm}^{2}$.

The Duong research group [63] further investigated the electrode's scaffold structure by determining the microstructure, electrochemical property, and enzyme loading. The interplay of the electrodes consists of chitosan, Nafion, and/or tripolyphosphate. The electrode comprising all chitosan, Nafion, and tripolyphosphate produced a high power of $1.077 \mathrm{~mW} / \mathrm{cm}^{2}$, compared with the electrode containing chitosan/tripolyphosphate and chitosan/Nafion. Another study used chitosan as the composite electrode, synthesized by 
Sufiaul Haque et al. [64] to increase porosity and surface area for highly optimized enzyme loading. The condition of glucose at $20 \mathrm{mM}$ produced a current density of $3.5 \mathrm{~mA} / \mathrm{cm}^{2}$ using the combination of chitosan/reduced graphene oxide/polyaniline as the electrode. Lv et al. [65] developed the carboxyl-functionalized mesoporous carbon electrode and used Nafion as an electron transfer medium. The carboxyl-functionalized mesoporous carbon electrode is optimized using oxidation time, concentration, and temperature as the main factors to increase enzyme activity and enzyme immobilization up to 140.72 and $242.74 \%$, respectively. There are various electrodes with a high density of the hydroxyl and amino groups in chitosan, which have the advantage of biocompatibility suitable for use in EBFC, and Kim et al. [66] combined them with cobalt metal and graphene oxide as a composite electrode to immobilize the enzyme. The authors claimed that improved electrochemical performance in EBFC affects rheological and morphological properties due to the acidity $\mathrm{pH}$ of the chitosan.

Shakeel et al. [15] produced electrode material without binder or adhesive using a combination of reduced graphene oxide ( $\mathrm{rGO}$ ), functionalized magnetic nanoparticles (f- $\mathrm{Fe}_{3} \mathrm{O}_{4}$ ), and polyaniline matrix. Biocompatible polymers with high conductivity, porosity, and surface area, together with the $\mathrm{rGO}$ and $\mathrm{f}-\mathrm{Fe}_{3} \mathrm{O}_{4}$ tested with appropriate enzyme loading, have increased electron transfer. The good electrical conductivity in graphene leads to the production of 3D graphene as a support for glucose oxidase with an extended enzyme lifetime and reduced leaching, developed by Babadi et al. [26]. The leaching is prevented by entrapping the enzyme at the $3 \mathrm{D}$ graphene surface and thus produces power at $164 \mu \mathrm{W} / \mathrm{cm}^{2}$. Three-dimensional graphene-related studies were also conducted by Werchmeister et al. [59] together with polyethylenimine (PEI) and ferrocene carboxylic acid $(\mathrm{FcCOOH})$ using the drop-casting method. This study also tested the effect of Nafion solution on 3D graphene/PEI/FCCOOH on the carbon paper surface. The catalytic activity reduced by about $20 \%$ in the stability test, and the electrode can be stored for a week at a temperature of $4{ }^{\circ} \mathrm{C}$. Butsyk et al. [67] synthesized the doped nitrogen and sulfur on carbon nano-onion as an enzyme support, in which the carbon nano-onion has properties of the graphene layer. The nitrogen and doped sulfur change the carbon-nano-onion capacitance characteristics and are suitable for the $\mathrm{H}_{2} \mathrm{O}_{2}$ sensor in EBFC.

Reduced graphene oxide was dispersed on the 3D carbon paper electrode as a biocathode to minimize the aggregation problem of $\pi-\pi$ stacking in reduced graphene oxide (rGO) by Tang et al. [68]. This r-GO/3D carbon paper combination provides enzyme orientation and confinement control to increase direct electron transfer efficiency with modification at the rGO surface through linker molecule 4-aminobenzoic acid (4-ABA). The bilirubin oxidase enzyme used in this study increased the half-life by 5 hours. Kuroishi et al. [69] used a modified electrode using the graphene-coated carbon fiber to help solve insufficient oxygen dissolved in the fuel liquid. Using graphene-coated carbon fiber with high porosity and surface area allowed the permeability of the oxygen gas to reach the electrode surface.

As stated earlier, the mediator is encouraged to be directly adsorbed on the electrode surface [28]. Shen et al. [70] took the initiative to produce the immobilized mediator redox protein cytochrome c (Cyt c) and used it on both anode and cathode. In addition, this material creates supercapacitor features that are for charge storage. The results show that the performance of EBFC was maintained at $80 \%$ when used as a 50 charge/discharge pulse. Kizling et al. [71] also developed an enzymatic biosupercapacitor using gold nanoparticlebased paper and nanostructured polypyrrole/nanocellulose as electrode materials with specific characteristics capacitance of $1.8 \mathrm{~F} / \mathrm{cm}^{2}$. The supercapacitance gives one order magnitude of the current and power densities compared in the steady-state mode. A study by Niiyama et al. [44] modified the poly binder (vinylidene difluoride) and polytetrafluoroethylene (PTFE) on the MgO-templated carbon at the anode and cathode of the $\mathrm{EBFC}$, respectively. The enzyme used will be supported by $\mathrm{MgO} /$ porous carbon. PTFE will control the hydrophobicity of the cathode so that the mass transport of oxygen gas becomes easy. 
Gold $(\mathrm{Au})$ electrode is commonly used in the EBFC cathode for oxygen reduction reactions (ORR). Wang et al. [20] produced self-powered sensors using EBFC to detect atrazine. To achieve use of the EBFC as a sensor, the authors used aptamers (Apt) supported on the Au electrode on the cathode section. ATZ was present at the cathode chamber and then bound at the Apt/Au electrode. The Apt/Au electrode has high sensitivity because it can detect ATZ as low as $7.5 \mathrm{mM}$ due to the Au electrode helping to increase the electron transferability. Although a Pt metal catalyst showed good catalysis in ORR, Ji et al. [72] developed an iron and cobalt co-doped ordered mesoporous porphyrinic carbon (FeCo-OMPC) biocathode for cheaper ORR and achieved long-term stability. ORR activity increased with cobalt metal in the biocathode with a limited power density of $21.3 \mu \mathrm{W} / \mathrm{cm}^{2}$ compared to without cobalt metal $\left(9.6 \mu \mathrm{W} / \mathrm{cm}^{2}\right)$. Mazar et al. [73] used the combination of gold nanoparticle-reduced graphene oxide and a poly neutral red polymer composite electrode to interact with both enzymes at the bioanode and biocathode. Combining the gold nanoparticle-reduced graphene oxide increases the stability, selectivity, and high chemical structure by interacting with the poly neutral red polymer that enhances the electron transfer and thus operates the EBFC at $0.2 \mathrm{~V}$ and power of $3.6 \mu \mathrm{W} / \mathrm{cm}^{2}$. Kwon et al. [74] focused on cathode studies to improve EBFC performance by using tris-(2-aminoethyl) amine (TREN) as a linker for the connection between $\mathrm{Au}$ nanoparticles and the surface of CNT fibers. TREN is used to reduce electron transfer resistance because TREN is a short molecule compared to other linkers/binders. These layer-by-layer Au nanoparticles produce power as high as $1.2 \mathrm{~mW} / \mathrm{cm}^{2}$.

The arrangement of the enzyme on the electrode surface plays a vital role so that the utilization of the enzyme can be maximized and provide excellent contact between the enzyme and the electrode surface. The work of Kizling et al. [75] resulted in cascade enzyme arrangement at the anode of the EBFC. In this study, various enzymes were used, namely mutarotase, invertase, fructose dehydrogenase, and flavine adenine dinucleotide (FAD)dependent glucose dehydrogenase in addition to using single or mixed substrates such as glucose, fructose, and sucrose. The comparison of other studies in this study shows that the resulting bioanode can produce a current as high as $2230 \mu \mathrm{A} / \mathrm{cm}^{2}$ and maintain power generation for eight days before falling by $38 \%$. Enzyme arrangement using nanoparticles that have a high surface area to volume ratio for enzyme loading [16] leads to a reduction in the distance of electron transport [75] and thus enhances the performance and stability of the EBFC [33].

EBFC can be applied as self-powered sensors to detect environmental pollutants. Pollutants such as atrazine are very harmful to humans and the environment, even at low ppb levels. Therefore, application of the EBFC as a biosensor electrode should have the ability to detect and quantify different analytes, good anti-interference performance [3], and lead to more efficient energy generation [42]. The diagram in Figure 6 shows the working schematic of the self-powered sensors using EBFC. Applications using EBFC as a biosensor need to develop electrodes using specific materials that can detect target molecules. Yu et al. [76] used EBFC for the detection of pathogenic bacteria. As shown in Figure 6, the aptamer is added in the developed system, and attached at the electrode surface, which is used to catch bacterial pathogens. Conventionally, in the absence of pathogens, glucose will be oxidized and generate electricity. The presence of pathogens will be trapped in the aptamer and will prevent glucose from oxidizing. 


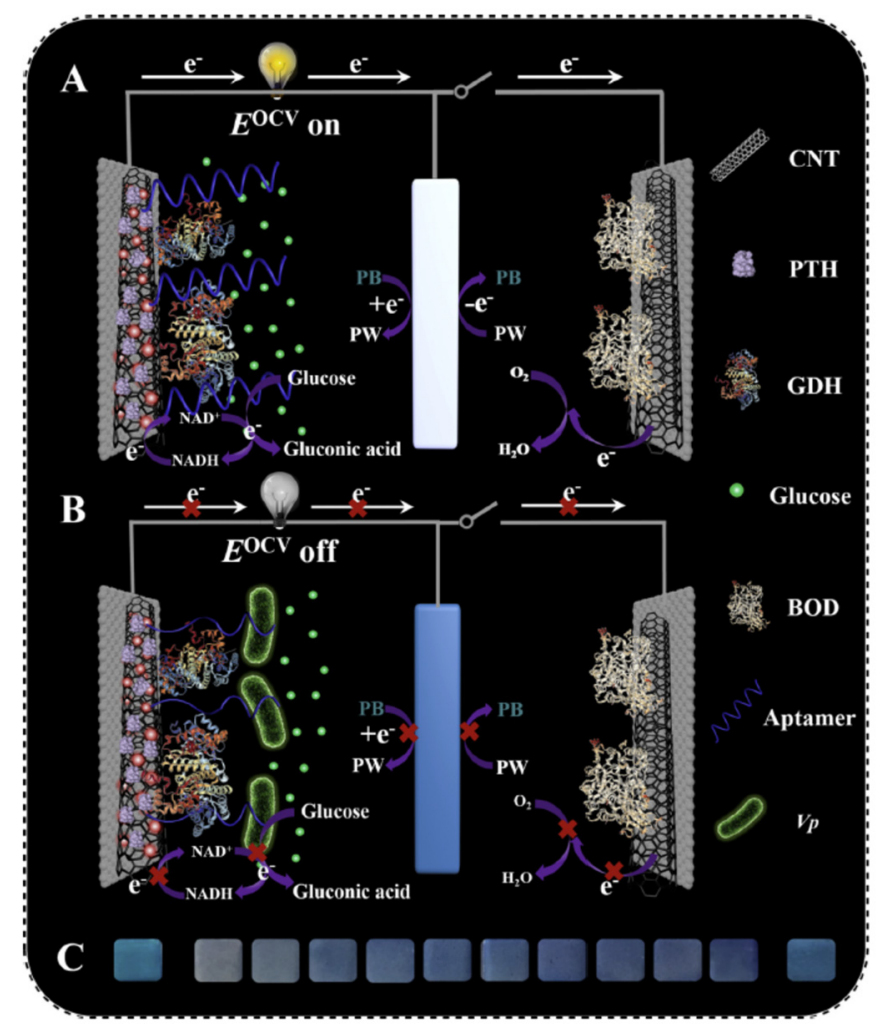

Figure 6. Schematic illustration of EBFCs-based self-powered biosensor with the visual self-checking function for Vp determination. (A) GDH would oxidize glucose to generate electrons, which could reduce blue PB to white PW; (B) when connected with the biocathode electrode, the PW electrode would be oxidized to the original PB state and $(C)$ the color conversion between PB and PW realized the self-checking function via visual detection [76]. Copyright 2020 Elsevier.

Immobilization of laccase enzyme (LAC) using the encapsulation technique through the highly porous and large surface area of the metal-organic frameworks (zeolitic imidazolate framework-8, ZIP-8) for both the anode and cathode was carried out by Li et al. [3]. To increase biocompatibility in the EBFC electrode, LAC-ZIP-8 is supported on a combination of bacterial cellulose and CNTs. The resulting EBFC system can detect bisphenol A (BPA) linearly by increasing the concentration of BPA due to the good anti-interference performance improvement of the enzyme's thermal, organic solvent, and pH stability using the ZIP-8. Adachi et al. [60] introduced the platinum nanoparticle (Pt) in the enzyme-Au electrodes interaction to achieve the DET process. The enzyme used commonly requires a mediator, flavin adenine dinucleotide-dependent glucose dehydrogenase (FAD-GDH). The Pt nanoparticle synthesized is located close to the enzyme, but the current difference produced without Pt is $1 \mathrm{~mA} / \mathrm{cm}^{2}$. Wang et al. [12] introduced the $\mathrm{SnS}_{2}$ nanoflower/Au nanoparticles as a support material for thrombin detection. The presence of $\mathrm{SnS}_{2}$ nanoflower/ $\mathrm{Au}$ nanoparticles has shown that the resulting electrode has capacitor characteristics and produces very high sensitivity detection (18.4 times) compared to a standard electrode. All developed electrode materials are summarized in Table 1. 
Table 1. Summarized development of the electrode materials in EBFC.

\begin{tabular}{|c|c|c|c|c|c|c|}
\hline Enzyme & Electrode Materials & Electrode Size & $\begin{array}{l}\text { Storage Conditions/ } \\
\text { Lifetime/Stability }\end{array}$ & $\begin{array}{c}\text { Working Conditions/Response } \\
\text { Time/Measurement Range }\end{array}$ & Performance & Ref \\
\hline $\begin{array}{l}\text { Glucose oxidase } \\
\text { (GOx) }\end{array}$ & $\begin{array}{c}\text { Kraton/MWCNTs; } \\
\text { mediator = ferritin (Frt); } \\
\text { glassy carbon electrode (GCE) }\end{array}$ & $3 \mathrm{~mm}$ diameter & - & $\begin{array}{l}\text { 1M PBS (pH 7.0) solution at an } \\
\text { ambient temperature at a scan rate } \\
\text { of } 100 \mathrm{mV} / \mathrm{s}\end{array}$ & $\begin{array}{c}\text { Current density }=1.14 \mathrm{~mA} / \mathrm{cm}^{2} \\
\text { at } 60 \mathrm{mM}\end{array}$ & [1] \\
\hline $\begin{array}{l}\text { Glucose oxidase } \\
\text { (GOx) }\end{array}$ & $\begin{array}{c}\text { Multi-walled carbon } \\
\text { nanotube-pyrene carboxylic } \\
\text { acid (MWCNTePCA) } \\
\text { nanocomposite; carbon } \\
\text { cloth (CC) }\end{array}$ & $4 \mathrm{~cm}^{2}$ & - & $\begin{array}{l}\text { PBS solution }(\mathrm{pH} 7.4)\left(\mathrm{N}_{2} \text { saturated }\right) \\
\text { containing } 500 \mathrm{mM} \text { glucose }\end{array}$ & $\begin{array}{c}\mathrm{OCP}=140 \mathrm{mV} \text {, peak power } \\
\text { density }=6.25 \mu \mathrm{W} / \mathrm{cm}^{2} \text { at } \\
60 \mu \mathrm{A} / \mathrm{cm}^{2}\end{array}$ & [2] \\
\hline $\begin{array}{l}\text { Glucose oxidase } \\
\text { (GOx) and } \\
\text { Laccase (LAC) }\end{array}$ & $\begin{array}{c}\text { Zeolitic imidazolate } \\
\text { framework-8 (ZIF-8), bacterial } \\
\text { cellulose }(\mathrm{BC}) / \text { carboxylated } \\
\text { multi-walled carbon } \\
\text { nanotubes (c-MWCNTs) }\end{array}$ & - & $\begin{array}{l}\text { After being stored at } 4^{\circ} \mathrm{C} \text { for } \\
20 \text { days, the residual activity of free } \\
\text { LAC retained was only } 38 \% \text {, while } \\
\text { the ZIF- } 8 \text {-LAC retained fairly } \\
\text { residual activity at } 53 \%\end{array}$ & $\begin{array}{l}\text { Linear dynamic range from } 0.01 \text { to } \\
0.4 \mathrm{mM} \text { with a lower detection limit } \\
\text { of } 1.95 \times 10^{-3} \mathrm{mM} \text { for } \\
\text { BPA concentrations }\end{array}$ & $\begin{array}{l}\text { Maximal power density of } \\
3.68 \mathrm{~W} / \mathrm{m}^{3}\end{array}$ & [3] \\
\hline $\begin{array}{l}\text { Glucose oxidase } \\
\text { (GOx); glucose } \\
\text { dehydrogenase } \\
\text { (GDH; favin } \\
\text { adenine } \\
\text { dinucleotide } \\
\text { (FAD)- } \\
\text { dependent), and } \\
\text { laccase (LAC) }\end{array}$ & $\begin{array}{c}\text { Mediator (PAA-PVI- } \\
\text { [Os(dmobpy)2Cl]+/2+), and } \\
\text { PEGDGE (4:4:1 v/v\%); BOD } \\
(10 \mathrm{U} / \mathrm{mL} \text { in PBS), PAA-PVI- } \\
{[\text { Os }(\mathrm{dCl}-\mathrm{bpy}) 2 \mathrm{Cl}]+/ 2+} \\
(0.5 \mathrm{mg} / \mathrm{mL} \text { in } \mathrm{DW}), \text { and } \\
\text { PEGDGE }(10.0 \mathrm{mg} / \mathrm{mL} \text { in DW) } \\
\text { in a 4:4:1 volume ratio }(\mathrm{v} / \mathrm{v} \%)\end{array}$ & - & $\begin{array}{l}20 \% \text { of the power density remained } \\
\text { after } 24 \mathrm{~h} \text { incubation in } 25 \mathrm{mM} \\
\text { glucose (in 1X PBS) compared to the } \\
\text { initial power density }\end{array}$ & $\begin{array}{c}-0.4 \text { to } 0.8 \mathrm{~V} \text { scan range and } \\
0.01 \mathrm{~V} / \mathrm{s} \text { scan rate at } 25^{\circ} \mathrm{C} ; \\
\text { increases in cell viability }(\sim 150 \%) \\
\text { and cell migration }(\sim 90 \%) \text { with a } \\
\text { relatively low } \\
\text { inflammatory response }\end{array}$ & $\begin{array}{l}\text { Power densities of } 15.26 \text { to } \\
38.33 \mathrm{nW} / \mathrm{cm}^{2} \text { depending on } \\
\text { the enzyme concentration in } \\
\text { media supplemented with } \\
25 \mathrm{mM} \text { glucose; extreme } \\
\text { cytotoxicity }(\sim 10 \%) \text { due to the } \\
\text { lethal concentration of } \mathrm{H}_{2} \mathrm{O}_{2} \\
\text { byproducts }(\sim 1500 \mu \mathrm{M})\end{array}$ & [6] \\
\hline Laccase (LAC) & $\begin{array}{c}\text { Carbon nanotubes (CNTs), } \\
\text { bacterial cellulose (BC), } \\
\text { amidoxime-modified BC, } \\
\text { carboxylated } \\
\text { multi-walled CNTs }\end{array}$ & - & $\begin{array}{c}\text { The residual activities of } \\
\text { AOBC/c-MWCNTs-LAC and } \\
\text { AOBC-LAC/c-MWCNTs remained } \\
\text { at } 44 \% \text { and } 61 \% \text { of the initial } \\
\text { catalytic activity after } 10 \text { reuse } \\
\text { times, respectively }\end{array}$ & $\begin{array}{c}\text { Anode and cathode were separated } \\
\text { by a proton exchange membrane of } \\
\text { Nafion ( } 5 \mathrm{wt} \%) \text {, buffer solution } \\
\text { (pH 4.5) acted as the electrolyte in } \\
\text { cathode chamber }\end{array}$ & $\begin{array}{c}\mathrm{OCV}=0.14 \mathrm{~V}, \text { power density } \\
\text { at } 1.897 \mathrm{~W} / \mathrm{cm}^{3}\end{array}$ & [7] \\
\hline $\begin{array}{l}\text { Glucose oxidase } \\
\quad(\text { GOx })\end{array}$ & $\begin{array}{l}\text { Metallic cotton fibers, gold } \\
\text { nanoparticles }\end{array}$ & $\begin{array}{l}\text { Diameter } 200 \mu \mathrm{m} \text {, } \\
\text { length } 5.0-\mathrm{mm} \text {, } \\
\text { active external } \\
\text { surface area } \\
3.14 \mathrm{~mm}^{2}\end{array}$ & & $\begin{array}{c}\text { Scan rate of } 5 \mathrm{mV} / \mathrm{s} \text { in a } \\
\text { phosphate-buffered saline } \\
\text { (PBS) solution }\end{array}$ & Power density $=3.7 \mathrm{~mW} / \mathrm{cm}^{2}$ & [9] \\
\hline
\end{tabular}


Table 1. Cont.

\begin{tabular}{|c|c|c|c|c|c|c|}
\hline Enzyme & Electrode Materials & Electrode Size & $\begin{array}{l}\text { Storage Conditions/ } \\
\text { Lifetime/Stability }\end{array}$ & $\begin{array}{l}\text { Working Conditions/Response } \\
\text { Time/Measurement Range }\end{array}$ & Performance & Ref \\
\hline $\begin{array}{c}\text { Oxalate } \\
\text { decarboxylase } \\
\text { (ethanol as fuel) }\end{array}$ & $\begin{array}{c}\text { Pyrene-TEMPO }(2,2,6,6- \\
\text { tetramethylpiperidinyl-N- } \\
\text { oxyl), carboxylated } \\
\text { multi-walled carbon nanotube, } \\
\text { carbon paper }\end{array}$ & $1 \mathrm{~cm}^{2}$ & $\begin{array}{l}\text { A stable amperometric curve and an } \\
\text { excellent current density value over } \\
\text { a duration of } 10 \mathrm{~h} \text {; after } 30 \text { days of } \\
\text { storage the electrode showed } 14 \% \\
\text { loss in power density }\end{array}$ & $\begin{array}{l}\text { Able to oxidize ethanol to } \mathrm{CO}_{2} \text { after } \\
10 \mathrm{~h} \text { of electrolysis }\end{array}$ & $\begin{aligned} \mathrm{OCP}= & 598 \mathrm{mV}, \text { power density } \\
= & 388 \mathrm{~W} / \mathrm{cm}^{2}\end{aligned}$ & [10] \\
\hline $\begin{array}{l}\text { Glucose oxidase } \\
\quad(\mathrm{GOx})\end{array}$ & $\begin{array}{c}\mathrm{SnS}_{2} \text { nanoflowers } / \mathrm{Au} \\
\text { nanoparticles, DNA-carbon } \\
\text { nanotubes bioconjugate, } \\
\text { aptamer }\end{array}$ & $\begin{array}{c}\mathrm{CP} \\
(0.5 \mathrm{~cm} \times 0.5 \mathrm{~cm})\end{array}$ & $\begin{array}{l}\text { Continuous operation for } 2000 \mathrm{~s}, \\
\text { EOCV remained about } 98 \%, \\
\text { demonstrating the self-powered } \\
\text { biosensor has a good stability }\end{array}$ & $\begin{array}{c}\text { Sensitivity of } 42.4 \mu \mathrm{A} /(\mathrm{ng} / \mathrm{mL}) \text { can } \\
\text { be discharged with an increase of } \\
18.4 \text { times that of pure EBFCs; } \\
\text { exhibited a wide linear range } \\
(0.02-5 \mathrm{ng} / \mathrm{mL}) \text { and a low detection } \\
\text { limit }(7.90 \mathrm{pg} / \mathrm{mL})\end{array}$ & - & [11] \\
\hline $\begin{array}{l}\text { Glucose oxidase } \\
\text { (GOx) and } \\
\text { bilirubin oxidase } \\
\text { (BOD) }\end{array}$ & $\begin{array}{l}\text { Nitrogen-doped ultra-thin } \\
\text { carbon shell/gold } \\
\text { nanoparticles }\end{array}$ & $\begin{array}{l}\text { Carbon paper }(\mathrm{CP}) \\
\text { electrode } \\
(1 \mathrm{~cm} \times 1 \mathrm{~cm})\end{array}$ & $\begin{array}{l}\text { The EOCV kept almost unchanged } \\
\text { after 5-days save, and it still } \\
\text { remained at } 98.63 \% \text { after two weeks, } \\
\text { suggesting good stability }\end{array}$ & $\begin{array}{c}\text { A wide linear range of } \\
0.1-2000 \mathrm{ng} / \mathrm{mL} \text { with a low } \\
\text { detection limit of } 21.5 \mathrm{pg} / \mathrm{mL} \\
(\mathrm{S} / \mathrm{N}=3)\end{array}$ & - & [12] \\
\hline $\begin{array}{l}\text { Flavin adenine } \\
\text { dinucleotide- } \\
\text { dependent } \\
\text { glucose } \\
\text { dehydrogenase }\end{array}$ & $\begin{array}{l}\text { Cellulose nanofiber, } \\
\text { multi-walled carbon } \\
\text { nanotubes, }\end{array}$ & $10 \times 5 \mathrm{~mm}^{2}$ & - & $\begin{array}{c}30 \mathrm{mmol} \mathrm{dm} 3 \text { glucose at a potential } \\
\text { sweep rate of } 10 \mathrm{mV} / \mathrm{s} . \\
\text { Temperature range: } 15-18^{\circ} \mathrm{C}\end{array}$ & $\begin{array}{c}\text { The maximum voltage and } \\
\text { maximum current density of } \\
\text { the biofuel cell were } 434 \mathrm{mV} \\
\text { and } 176 \mathrm{~mA} / \mathrm{cm}^{2} \text {, respectively, } \\
\text { at room temperature } \\
\left(15-18^{\circ} \mathrm{C}\right) . \text { The maximum } \\
\text { power output was } \\
27 \mathrm{~mW} / \mathrm{cm}^{2}\end{array}$ & [14] \\
\hline $\begin{array}{l}\text { Glucose oxidase } \\
\quad(\mathrm{GOx})\end{array}$ & $\begin{array}{l}\text { Reduced graphene oxide } \\
\text { (rGO) and functionalized } \\
\text { magnetic nanoparticles } \\
\text { (f- } \mathrm{Fe}_{3} \mathrm{O}_{4} \mathrm{NPs} \text { ) in polyaniline } \\
\text { matrix }\end{array}$ & $\begin{array}{l}3 \text { mm diameter } \\
\text { glassy carbon } \\
\text { electrode }\end{array}$ & $\begin{array}{l}\text { The lifetime of the } \\
\mathrm{rGO} / \mathrm{PANI} / \mathrm{f}-\mathrm{Fe}_{3} \mathrm{O}_{4} / \mathrm{Frt} / \mathrm{GOx} \\
\text { bioelectrode when stored at } 4{ }^{\circ} \mathrm{C} \\
\text { was estimated to be } 45 \text { days }\end{array}$ & $\begin{array}{c}0.3 \mathrm{M} \\
{\left[\mathrm{K}_{4} \mathrm{Fe}(\mathrm{CN})_{6}\right] \text { as supporting }} \\
\text { electrolyte at ambient conditions }\end{array}$ & $\begin{array}{l}\text { Maximum current density of } \\
32.9 \mathrm{~mA} / \mathrm{cm}^{2} \text { at the optimum } \\
\text { glucose concentration of } \\
50 \mathrm{mM}\end{array}$ & [15] \\
\hline $\begin{array}{l}\text { Glucose oxidase } \\
\quad(\text { GOx })\end{array}$ & $\begin{array}{c}\text { Polythiophene@NiO/Frt/Gox, } \\
\text { nano-inspired nickel oxide } \\
\text { nanoparticles }(\mathrm{NiO}) \text { and } \\
\text { polythiophene (Pth), mediator } \\
\text { ferritin }\end{array}$ & $\begin{array}{l}\text { Glassy carbon } \\
\text { electrode (GCE) }\end{array}$ & $\begin{array}{l}\text { Electrode was kept in the } \\
\text { refrigerator at } 4{ }^{\circ} \mathrm{C} \text { prior to use }\end{array}$ & $\begin{array}{l}40 \mathrm{mM} \text { glucose dissolved in PBS of } \\
\text { pH } 7.0\end{array}$ & $\begin{array}{l}\text { The current density of } \\
\text { Pth@NiO/Frt/GOx bioanode } \\
\text { was found to be } 5.4 \mathrm{~mA} / \mathrm{cm}^{2}\end{array}$ & [16] \\
\hline
\end{tabular}


Table 1. Cont.

\begin{tabular}{|c|c|c|c|c|c|c|}
\hline Enzyme & Electrode Materials & Electrode Size & $\begin{array}{l}\text { Storage Conditions/ } \\
\text { Lifetime/Stability }\end{array}$ & $\begin{array}{l}\text { Working Conditions/Response } \\
\text { Time/Measurement Range }\end{array}$ & Performance & Ref \\
\hline $\begin{array}{l}\text { Glucose oxidase } \\
\text { (GOx) }\end{array}$ & $\begin{array}{l}\text { Chitosan-modified carbon } \\
\text { cloth via tripolyphosphate }\end{array}$ & $\operatorname{CCs}\left(8.2 \times 8.2 \mathrm{~cm}^{2}\right)$ & $\begin{array}{l}\text { The cell right after each testing was } \\
\text { stored in a refrigerator at }-4{ }^{\circ} \mathrm{C} \text {, as } \\
\text { suggested by the enzyme } \\
\text { manufacturer, to prevent the } \\
\text { degradation of GOx from } \\
\text { ambient temperature }\end{array}$ & $\begin{array}{c}\text { Phosphate-buffered saline (PBS, } \\
\mathrm{pH} \frac{1}{4} \text { 7) with and without } 0.1 \mathrm{M} \\
\mathrm{C}_{6} \mathrm{H}_{12} \mathrm{O}_{6} \text { at } 100 \mathrm{mV} / \mathrm{s}\end{array}$ & $\begin{array}{c}53 \% \text { improvement in area power } \\
\text { density; efficient area and } \\
\text { volume power density of } 0.549 \\
\mathrm{~mW} / \mathrm{cm}^{2} \text { and } 114.52 \mathrm{~mW} / \mathrm{cm}^{3}\end{array}$ & [17] \\
\hline $\begin{array}{l}\text { Glucose } \\
\text { dehydrogenase } \\
\text { (GDH) }\end{array}$ & $\begin{array}{c}\text { Cathode }=\text { aptamers }(\text { Apt }) \text { and } \\
\text { Au, anode = carboxylated } \\
\text { multi-walled carbon } \\
\text { nanotubes }\end{array}$ & $\begin{array}{l}\text { Anode = glassy } \\
\text { carbon electrode } \\
(\mathrm{GCE}) ; \text { cathode }= \\
\text { Au electrode } \\
(\mathrm{d}=3 \mathrm{~mm})\end{array}$ & $\begin{array}{l}\text { Stored at } 4{ }^{\circ} \mathrm{C} \text {; the relative power } \\
\text { output ratio and the relative ratio } \\
\text { (R)-R\% values in the presence of } \\
\text { these pollutants were all less than } \\
10 \% \text {; the EOCV was maintained at } \\
\text { over } 95 \% \text { after } 9 \mathrm{~h} \text { of } \\
\text { continuous operation }\end{array}$ & ATZ detection limit $7.5 \mathrm{nM}$ & $\begin{array}{l}\text { The self-powered Pmax reached } \\
\qquad 15.3 \mu \mathrm{W} / \mathrm{cm}^{2}\end{array}$ & {$[20]$} \\
\hline $\begin{array}{l}\text { Glucose oxidase } \\
\text { (GOx) }\end{array}$ & $\begin{array}{c}\text { Defective NiMoSe2 } \\
\text { nanoplates, functionalized } \\
\text { SWCNTs doped polypyrrole, }\end{array}$ & GCE $0.07 \mathrm{~cm}^{2}$ & - & $\begin{array}{l}\text { PBS (pH 7.0) as supporting } \\
\text { electrolyte at ambient conditions; } \\
50 \mathrm{mM} \text { glucose concentration }\end{array}$ & $\begin{array}{l}\text { Open circuit potential }(\mathrm{OCV}) \text { of } \\
0.35 \mathrm{~V} \text { and delivered the } \\
\text { maximum current density of } \\
9.01 \mathrm{~mA} / \mathrm{cm}^{2} \text { in } 50 \mathrm{mM} \text { glucose } \\
\text { concentration }\end{array}$ & {$[21]$} \\
\hline $\begin{array}{l}\text { Glucose oxidase } \\
\text { (GOx) }\end{array}$ & SWCNTs, gold nanoparticles & $\begin{array}{l}\text { Indium tin oxide } \\
\text { (ITO) electrodes } \\
1.25 \mathrm{~cm} \times 2.75 \mathrm{~cm}\end{array}$ & $\begin{array}{l}\text { Cell voltage was maintained at } \\
0.54 \mathrm{~V} \text { under } 66.7 \mathrm{uA} / \mathrm{cm}^{2} \text { of } \\
\text { discharge current density for } 48 \mathrm{~h}\end{array}$ & $\begin{array}{l}\text { PBS (pH 7.0) supplemented with } \\
30 \mathrm{mM} \text { of glucose at scan rate of } \\
10 \mathrm{mV} / \mathrm{s}\end{array}$ & $\begin{array}{c}\text { Maximum power density of } 38.2 \\
\pm 2.0 \mu \mathrm{W} / \mathrm{cm}^{2} \text { at } 0.57 \pm 0.03 \mathrm{~V} \\
\text { of a cell voltage }\end{array}$ & {$[22]$} \\
\hline $\begin{array}{l}\text { Glucose oxidase } \\
\text { (GOx) }\end{array}$ & Three-dimensional graphene & $\begin{array}{l}\text { GCE, diameter } \\
3 \mathrm{~mm}\end{array}$ & - & $\begin{array}{c}\text { Scan rate } 50 \mathrm{mV} / \mathrm{s} \text { and the } \\
\text { solution PBS }\end{array}$ & $\begin{array}{c}\text { Power density of } 164 \mathrm{~mW} / \mathrm{cm}^{2} \\
\text { at } 0.4 \mathrm{~V}\end{array}$ & [26] \\
\hline $\begin{array}{l}\text { Oxalate oxidase } \\
\text { (ethanol as fuel) }\end{array}$ & $\begin{array}{l}\text { TEMPO-modified linear } \\
\text { poly(ethylenimine) (LPEI), } \\
\text { carboxylated multi-walled } \\
\text { carbon nanotubes } \\
\text { (MWCNT-COOH) }\end{array}$ & GC electrode & - & $\begin{array}{c}50 \mathrm{mM} \text { citric acid-phosphate } \\
\text { buffers, } \mathrm{pH}=5.5, \\
v=10 \mathrm{mV} / \mathrm{s} \text { and } 25^{\circ} \mathrm{C}\end{array}$ & - & {$[27]$} \\
\hline $\begin{array}{l}\text { Glucose oxidase } \\
\text { (GOx) }\end{array}$ & $\begin{array}{l}\text { Cross-linking of chitosan and } \\
\text { genipin, 4-nitrobenzoic acid } \\
\text { mediator, carbon nanotube }\end{array}$ & - & - & $\begin{array}{c}0.01 \mathrm{M} \text { PBS }(\mathrm{pH} 7.4) \\
\text { electrolyte, while } 20 \mathrm{mM} \text { glucose } \\
\text { was injected }\end{array}$ & $\begin{array}{c}\text { Anodic current }\left(331 \mu \mathrm{A} / \mathrm{cm}^{2} \text { at }\right. \\
0.3 \mathrm{~V} \text { vs. } \mathrm{Ag} / \mathrm{AgCl}) \text { with a low } \\
\text { onset potential }(0.05 \mathrm{~V} \text { vs. } \\
\mathrm{Ag} / \mathrm{AgCl}) ; \text { open-circuit voltage } \\
\text { of } 0.54 \mathrm{~V} \text { and a maximum power } \\
\text { density of } 38 \mu \mathrm{W} / \mathrm{cm}^{2}\end{array}$ & {$[28]$} \\
\hline
\end{tabular}


Table 1. Cont.

\begin{tabular}{|c|c|c|c|c|c|c|}
\hline Enzyme & Electrode Materials & Electrode Size & $\begin{array}{l}\text { Storage Conditions/ } \\
\text { Lifetime/Stability }\end{array}$ & $\begin{array}{l}\text { Working Conditions/Response } \\
\text { Time/Measurement Range }\end{array}$ & Performance & Ref \\
\hline $\begin{array}{l}\text { Glucose oxidase } \\
\text { (GOx) }\end{array}$ & $\mathrm{Fe}_{3}(\mathrm{CN})_{6}$,polypyrrole, $\mathrm{CNB}$ & $\begin{array}{l}\text { Carbon paper } \\
\qquad 1 \mathrm{~cm}^{2}\end{array}$ & Stored at $4{ }^{\circ} \mathrm{C}$ & $\begin{array}{l}\text { The measurements were performed } \\
\text { at a working temperature of } 37^{\circ} \mathrm{C} \\
\text { with phosphate-buffered solution of } \\
\text { pH } 7 \text { as an electrolyte, and } 10 \mathrm{mM} \\
\text { glucose was added to the anode as } \\
\text { a fuel }\end{array}$ & $\begin{array}{l}\text { Continuous } 16 \mathrm{~h} \text {, the } \\
\text { maximum power density } \\
\text { achieved for a hydrophobic } \\
\text { electrode was approximately } \\
80 \mathrm{\mu W} / \mathrm{cm}^{2} \text { at } 0.13 \mathrm{~V}\end{array}$ & [29] \\
\hline $\begin{array}{l}\text { Glucose oxidase } \\
\qquad(\mathrm{GOx})\end{array}$ & $\begin{array}{l}\text { Amine-containing osmium } \\
\text { redox complexes, genipin to } \\
\text { crosslink chitosan, } \\
\text { Functionalised MWCNTs }\end{array}$ & - & $\begin{array}{l}\text { Genipin cross-linked hydrogels } \\
\text { delivered a 3-fold increase in } \\
\text { stability for continuous } \\
\text { amperometric current production } \\
\text { over a } 20 \mathrm{~h} \text { period; } 13 \% \text { activity } \\
\text { retained after } 20 \mathrm{~h} \text {; very low } \Gamma \text { Os } \\
\text { retention }(16 \% \text { retained after } 20 \mathrm{~h})\end{array}$ & $\begin{array}{c}50 \mathrm{mM} \text { phosphate-buffered saline } \\
(150 \mathrm{mM} \mathrm{NaCl}, \\
\left.\mathrm{pH} 7.4,37^{\circ} \mathrm{C}\right) \text { containing } 100 \mathrm{mM} \\
\text { glucose }\end{array}$ & $\begin{array}{c}\text { Glucose oxidation current } \\
\text { densities of } 730 \mu \mathrm{A} / \mathrm{cm}^{2} \text { at an } \\
\text { applied potential of } 0.45 \mathrm{~V} \text { (vs. } \\
\mathrm{Ag} / \mathrm{AgCl})\end{array}$ & {$[30]$} \\
\hline $\begin{array}{l}\text { Alcohol } \\
\text { deshydrogenase } \\
(\mathrm{ADH})\end{array}$ & $\begin{array}{c}\text { Tetrabutylammonium } \\
\text { bromide and Nafion and } \\
\text { subsequently immobilized on } \\
\text { TiO2 nanotubes (TNT), NAD+ }\end{array}$ & $\begin{array}{l}\quad 2 \times 0.3 \mathrm{~cm} \\
\text { titanium dioxide } \\
\text { nanotube plate }\end{array}$ & $\begin{array}{l}\text { Optimal conditions for preserving } \\
70 \% \text { of the enzymatic activity }\end{array}$ & $\begin{array}{c}\text { The assays were carried out at } \\
25^{\circ} \mathrm{C} \text {, using } 15 \text { min of reaction time; } \\
\text { pH } 8.86 \text { and } 35^{\circ} \mathrm{C}\end{array}$ & $\begin{array}{c}\text { Open circuit potential greater } \\
\text { than } 0.9 \mathrm{~V} ; 5.93 \mathrm{~mW} / \mathrm{cm}^{2} \text { of } \\
\text { power density operating at } \\
1.0 \mathrm{~V}\end{array}$ & {$[33]$} \\
\hline $\begin{array}{l}\text { Glucose oxidase } \\
\text { (GOx); laccase }\end{array}$ & $\begin{array}{l}\text { Transition-metal-doped } \\
\text { molybdenum diselenides } \\
\text { (NiMoSe2); }\end{array}$ & $\begin{array}{l}\text { Nickel foam } \\
1 \times 1 \mathrm{~cm}^{2}\end{array}$ & $\begin{array}{l}\text { The oxidation current response was } \\
\text { recorded before and after } 24 \mathrm{~h} \\
\text { electrode storage in electrolyte } \\
\text { solution; cell kept } 89.5 \% \text { of its initial } \\
\text { performance after } 3 \text { days }\end{array}$ & $\begin{array}{c}1 \mathrm{mg} \text { of enzyme } / 1 \mathrm{~mL} \text { of phosphate } \\
\text { buffer, pH } 5\end{array}$ & $\begin{array}{c}\text { open-circuit voltage } \\
(\mathrm{VOC}=0.6 \mathrm{~V}) \text { and a } \\
\text { short-circuit current density } \\
\left(\mathrm{JSC}=8.629 \mathrm{~mA} / \mathrm{cm}^{2}\right) \text { with a } \\
\text { maximum power density } \\
\left(\text { Pmax) of } 1.2 \mathrm{~mW} / \mathrm{cm}^{2} ;\right. \\
\text { electrochemical } \\
\text { pseudocapacitor application, } \\
\text { the proposed NiMoSe } 2 / \mathrm{NF} \\
\text { exhibited excellent specific } \\
\text { capacitance }(535.74 \mathrm{~F} / \mathrm{g}), \text { with } \\
86.7 \% \text { rate performance }\end{array}$ & {$[37]$} \\
\hline $\begin{array}{l}\text { Two } \\
\text { dehydrogenases } \\
\text { and a diaphorase }\end{array}$ & - & $1 \mathrm{~cm}^{2}$ carbon felt & $\begin{array}{l}\text { The Tm6PGDHmutant } 3-3 \text { exhibited } \\
\text { a } 42 \text {-fold increase in catalytic } \\
\text { efficiency at pH } 5.4 \text { compared to the } \\
\text { original enzyme. }\end{array}$ & Anodic $\mathrm{pH}$ of 5.4 & $\begin{array}{l}\text { Maximum power density of } \\
0.13 \mathrm{~mW} / \mathrm{cm}^{2} \text { at } \mathrm{pH} 5.4\end{array}$ & {$[38]$} \\
\hline
\end{tabular}


Table 1. Cont.

\begin{tabular}{|c|c|c|c|c|c|c|}
\hline Enzyme & Electrode Materials & Electrode Size & $\begin{array}{l}\text { Storage Conditions/ } \\
\text { Lifetime/Stability }\end{array}$ & $\begin{array}{l}\text { Working Conditions/Response } \\
\text { Time/Measurement Range }\end{array}$ & Performance & Ref \\
\hline $\begin{array}{l}\text { Glucose oxidase } \\
\text { (GOx)- or laccase } \\
\text { (Lac)-modified }\end{array}$ & $\begin{array}{l}\text { Rectangular carbon tube } \\
\text { polypyrrole (RPPy) }\end{array}$ & $\begin{array}{l}\text { Glassy carbon } \\
\text { electrode }(\varphi 3 \mathrm{~mm}) \\
0.5 \times 0.5 \mathrm{~cm}^{2} \\
\text { nickel foam; } \\
2 \times 2 \mathrm{~cm}^{2} \text { nickel } \\
\text { foam }\end{array}$ & $\begin{array}{l}\text { Stored at } 4{ }^{\circ} \mathrm{C} \text {; after } 14 \text { days, the } \\
\text { power density was still } 82.02 \%\end{array}$ & $\begin{array}{c}\text { Anodic compartment was } 50 \mathrm{~mL} \\
\text { Ar-saturated 0.1 M SDA (pH 5.0) } \\
\text { with } 0.05 \mathrm{M} \text { glucose; the cathodic } \\
\text { compartment was filled with } 50 \mathrm{~mL} \\
0.1 \mathrm{M} \text { B-R buffer (pH 5.0) with } \\
0.5 \mathrm{mM} \text { ABTS and continuously } \\
\text { bubbled with oxygen; discharge } \\
\text { time reached } 49.9 \mathrm{~h} \text { at a discharge } \\
\text { current of } 0.2 \mathrm{~mA} \text { before the voltage } \\
\text { was lower than } 0.8 \mathrm{~V}\end{array}$ & $\begin{array}{l}\text { Open-circuit voltage reached } \\
1.16 \mathrm{~V} \text {; power density was } \\
\text { measured to } 0.350 \mathrm{~mW} / \mathrm{cm}^{2} \text {, } \\
\text { which correlated to the } \\
\text { gravimetric power density of } \\
0.265 \mathrm{~mW} / \mathrm{mg} \text { (per } \mathrm{mg} \text { of } \\
\text { GOx) at } 0.85 \mathrm{~V}\end{array}$ & [39] \\
\hline $\begin{array}{l}\text { GOx for } \\
\text { bioanode and } \\
\text { laccase for } \\
\text { biocathode }\end{array}$ & $\begin{array}{l}\text { 3D-printed carbon } \\
\text { bioelectrodes }\end{array}$ & $\begin{array}{l}20 \mathrm{~mm} \times 2 \mathrm{~mm} \times \\
1 \mathrm{~mm}(\text { length } \times \\
\text { width } \times \text { height })\end{array}$ & $\begin{array}{l}\text { Stored at } 4{ }^{\circ} \mathrm{C} ; \mathrm{CB} \text { bioanode } \\
\text { exhibited almost } 65.5 \% \text { of current } \\
\text { response of its first day whereas } \\
\text { AM bioanode showed about } 50 \% \text { of } \\
\text { performance of its first day }\end{array}$ & $\begin{array}{l}\text { Enzyme solutions of glucose } \\
\text { oxidase }(5 \mathrm{mg} / \mathrm{mL}, \mathrm{pH} 7) \text { and } \\
\text { laccase }(5 \mathrm{mg} / \mathrm{mL}, \mathrm{pH}) ; \\
\text { bioelectrodes were dried in } \\
\text { atmospheric conditions for } 2 \mathrm{~h} \text { and } \\
\text { preserved in } \mathrm{PBS} \text { at } 4^{\circ} \mathrm{C} \text { until use; } \\
\text { the electrolyte solutions consisted of } \\
\text { mediators such as } \mathrm{PBQ}(1 \mathrm{mM}, \\
\text { pH } 7) \text { and ABTS }(1 \mathrm{mM}, \mathrm{pH} 5) \text { in } \\
\text { anolyte and catholyte, respectively. }\end{array}$ & $\begin{array}{c}\text { CB bioelectrodes gave a power } \\
\text { density of } 0.1 \mu \mathrm{W} / \mathrm{cm}^{2} \text { with a } \\
\text { current density of } 3 \mu \mathrm{A} / \mathrm{cm}^{2} \\
\text { at an open circuit potential of } \\
105 \mathrm{mV}\end{array}$ & [40] \\
\hline $\begin{array}{l}\text { Glucose oxidase } \\
\text { (GOx) }\end{array}$ & $\begin{array}{c}\text { Hemin bonded with } \\
\text { amine-functionalized carbon } \\
\text { nanotube; poly(dimethyl- } \\
\text { diallylammonium } \\
\text { chloride) }\end{array}$ & $\begin{array}{l}\text { GCE, diameter of } \\
5 \mathrm{~mm}\end{array}$ & $\begin{array}{c}\text { Activity preserved } 82.1 \% \text { after } \\
\text { four weeks }\end{array}$ & $\begin{array}{l}0.01 \mathrm{M} \text { PBS (pH 7.4) was used as } \\
\text { electrolyte and potential scan rate } \\
\text { was } 20 \mathrm{mV} / \mathrm{s} \text { at } \mathrm{N}_{2} \text { state condition }\end{array}$ & $\begin{array}{c}\text { Membraneless EBFC adopting } \\
\text { this catalyst is measured, } \\
\text { maximum power density is } \\
24.1 \mathrm{~mW} / \mathrm{cm}^{2}\end{array}$ & [41] \\
\hline $\begin{array}{l}\text { Glucose oxidase } \\
\text { (GOx) }\end{array}$ & $\begin{array}{l}\text { Dimethylferrocene-modified } \\
\text { linear poly(ethyleneimine); } \\
\text { either glutaraldehyde (GA) or } \\
\text { ethylene glycol diglycidyl } \\
\text { ether (EGDGE) }\end{array}$ & - & $\begin{array}{l}\text { Stored at } 2-8{ }^{\circ} \mathrm{C} \text { for } 24 \mathrm{~h} ; 48 \% \text { of the } \\
\text { initial OCP value is retained after } \\
21 \text { days of storage; } 60 \% \text { of the initial } \\
\text { current density was lost in that } \\
\text { period of time }\end{array}$ & $\begin{array}{c}\text { Solutions of b-D-glucose in } 0.1 \mathrm{M} \\
\mathrm{pH} \frac{1}{4} 7.4 \mathrm{~PB} \text { were prepared at } \\
\text { concentrations ranging from } 0 \text { to } \\
10 \mathrm{mM} \text { in } 2 \mathrm{mM} \text { increments; } \\
\text { applying potentials from } 0.3 \text { to } \\
\text { p0.3 V vs. a } \mathrm{Ag} / \mathrm{AgCl} \\
\text { pseudoreference at scan rates }(\mathrm{n}) \text { of } \\
5 \mathrm{e} 500 \mathrm{mV} / \mathrm{s}\end{array}$ & $\begin{array}{l}\text { OCP of around } 0.82 \mathrm{~V} \text {, and a } \\
\text { maximum current and power } \\
\text { of about } 440 \mathrm{~mA} / \mathrm{cm}^{2} \text { and } \\
\qquad 86 \mathrm{~mW} / \mathrm{cm}^{2}\end{array}$ & [42] \\
\hline
\end{tabular}


Table 1. Cont.

\begin{tabular}{|c|c|c|c|c|c|c|}
\hline Enzyme & Electrode Materials & Electrode Size & $\begin{array}{l}\text { Storage Conditions/ } \\
\text { Lifetime/Stability }\end{array}$ & $\begin{array}{l}\text { Working Conditions/Response } \\
\text { Time/Measurement Range }\end{array}$ & Performance & Ref \\
\hline $\begin{array}{l}\text { Glucose oxidase } \\
\text { (GOx) }\end{array}$ & $\begin{array}{l}\text { Iron-nitrogen doped carbon } \\
\text { nanotube }(\mathrm{Fe}-\mathrm{N} / \mathrm{CNT}) \\
\text { polyethylenimine (PEI) }\end{array}$ & - & $\begin{array}{l}\text { Preserving } 81.2 \% \text { of its initial value } \\
\text { even after four weeks }\end{array}$ & $\begin{array}{l}\text { 0.01 M phosphate-buffered solution } \\
\text { (PBS, pH 7.4); } 0.03 \mathrm{M} \text { glucose } \\
\text { solution (air purge) was circulated } \\
\text { from an external bottle to the EBFC } \\
\text { kit at a flow rate of } 0.1 \mathrm{~mL} / \mathrm{min}, \\
\text { while within the cathode of the } \\
\text { membrane EBFC, } 0.01 \mathrm{M} \text { of } \\
\text { pH-adjusted PBS }\end{array}$ & $\begin{array}{l}\text { Onset potential and current } \\
\text { density }(0.17 \mathrm{~V} \text { and } \\
\left.74.3 \mu \mathrm{A} / \mathrm{cm}^{2}\right) \text { with the } \\
\text { injection of } 8 \mathrm{mM} \text { glucose } \\
\text { solution; constant and } \\
\text { maximum current density } \\
\text { were } 139.4 \mathrm{mM} \text { and } \\
347.1 \mu \mathrm{A} / \mathrm{cm}^{2}\end{array}$ & [43] \\
\hline $\begin{array}{l}\text { Flavin adenine } \\
\text { dinucleotide- } \\
\text { dependent } \\
\text { glucose } \\
\text { dehydrogenase } \\
\end{array}$ & $\begin{array}{l}\text { Carbon cloth modified with } \\
\text { MgO-templated porous } \\
\text { carbon; 1,4-naphthoquinone }\end{array}$ & 1.0 or $4.0 \mathrm{~cm}^{2}$ & $\begin{array}{l}\text { FAD-GDH exhibited } 30 \% \text { of the } \\
\text { initial activity }\end{array}$ & $\begin{array}{c}\mathrm{mV} \mathrm{s}^{-1} \text { in } 1.0 \mathrm{M} \\
\text { phosphate-buffered } \mathrm{pH} 7.0 ; 1.0 \mathrm{M} \\
\text { glucose }\end{array}$ & $\begin{array}{c}\text { Open circuit potential was } \\
0.75 \mathrm{~V} \text { and maximum output } \\
\text { power density was } 2 \mathrm{~mW} / \mathrm{cm}^{2} \\
\text { at } 0.4 \mathrm{~V}\end{array}$ & [44] \\
\hline $\begin{array}{l}\text { Sulfite oxidase } \\
\quad \text { (sulfite) }\end{array}$ & $\begin{array}{l}\text { Three-dimensional sulfite } \\
\text { oxidase; } \\
\text { graphene-functionalized } \\
\text { carbon paper }\end{array}$ & $0.50 \times 0.50 \mathrm{~cm}^{2}$ & $\begin{array}{l}\text { Loss rate remained at } 4-5 \% \text { of the } \\
\text { initial signal }\end{array}$ & $\begin{array}{l}\text { Oxygen-free Tris-acetate buffer } \\
\text { solutions }(750 \mathrm{mM}, \mathrm{pH} 8.4) \text { and } \\
1.0 \mathrm{mM} \mathrm{Na} \mathrm{SO}_{3} ; \text { scan rate, } 5 \mathrm{mV} / \mathrm{s}\end{array}$ & $\begin{array}{l}\text { Open-circuit voltage }(\mathrm{OCV}) \text { of } \\
0.641 \mathrm{~V} \text { and a maximum } \\
\text { power density of } 61 \mu \mathrm{W} / \mathrm{cm}^{2} \\
\left(122 \mathrm{~mW} / \mathrm{m}^{3}\right) \text { at } 30^{\circ} \mathrm{C}\end{array}$ & [45] \\
\hline $\begin{array}{l}\text { Pyrroloquinoline } \\
\text { quinone- } \\
\text { dependent } \\
\text { glucose } \\
\text { dehydrogenase } \\
\text { (PQQ-GDH) and } \\
\text { bilirubin oxidase } \\
\text { (BOx) }\end{array}$ & $\begin{array}{l}\text { Two-dimensional graphene } \\
\text { paper, Meldola blue (MB) }\end{array}$ & $0.25 \mathrm{~cm}^{2}$ & Stored at $4{ }^{\circ} \mathrm{C}$ & $\begin{array}{l}\text { 2D-GP electrode was immersed in a } \\
10 \mathrm{mM} \text { MB aqueous solution and } \\
\text { left overnight; } 10 \mathrm{mM} \\
\text { phosphate-buffered (PB) solution at } \\
\text { pH } 7.0 \text { was used as the electrolyte } \\
\text { for electrochemical experiments }\end{array}$ & $\begin{array}{l}\text { Open circuit voltage }=0.665 \mathrm{~V} ; \\
\text { maximum power density }= \\
4 \mathrm{~mW} / \mathrm{cm}^{2}\end{array}$ & [48] \\
\hline $\begin{array}{l}\text { Glucose oxidase } \\
\text { (GOx) or laccase } \\
\text { (Lac) }\end{array}$ & $\begin{array}{l}\text { Porous structured carbon } \\
\text { paper }(\mathrm{CP})\end{array}$ & $\begin{array}{l}\text { Diameter: } 2 \mathrm{~cm} \text {; } \\
\text { thickness: } 4 \mathrm{~mm} \text { for } \\
\text { one piece and } \\
1 \mathrm{~mm} \text { for the other } \\
4 \text { pieces }\end{array}$ & $\begin{array}{l}\text { Stored at } 4{ }^{\circ} \mathrm{C} \text {; the cell was operated } \\
\text { continuously for } 2000 \mathrm{~s} \text { in } 5 \mathrm{mM} \\
\text { glucose containing PB under } \\
\text { ambient air; it maintained } 75 \% \text { of } \\
\text { its power }\end{array}$ & $\begin{array}{c}\text { Cyclic voltammetry }(\mathrm{CV}) \text { in } 0.1 \mathrm{M} \text {, } \\
\mathrm{pH} 7.4 \mathrm{~PB} \text { containing } 0.4 \mathrm{mM} \\
\mathrm{HAuCl}_{4} \text { solution with a potential } \\
\text { scan rate of } 50 \mathrm{mV} / \mathrm{s} \text { and a scanning } \\
\text { range of } 1.0 \text { to } 0.5 \mathrm{~V} \text { for } 20 \text { cycles }\end{array}$ & $\begin{array}{l}9.64 \mathrm{~mW} / \mathrm{cm}^{2} \text { at } 0.43 \mathrm{~V} \text { and } \\
53.0 \mathrm{~mW} / \mathrm{cm}^{2} \text { at } 0.45 \mathrm{~V} \text { for the } \\
\text { cell in } 5 \mathrm{mM} \text { glucose }\end{array}$ & [50] \\
\hline
\end{tabular}


Table 1. Cont.

\begin{tabular}{|c|c|c|c|c|c|c|}
\hline Enzyme & Electrode Materials & Electrode Size & $\begin{array}{l}\text { Storage Conditions/ } \\
\text { Lifetime/Stability }\end{array}$ & $\begin{array}{l}\text { Working Conditions/Response } \\
\text { Time/Measurement Range }\end{array}$ & Performance & Ref \\
\hline $\begin{array}{l}\text { Flavin adenine } \\
\text { dinucleotide- } \\
\text { dependent } \\
\text { glucose } \\
\text { dehydrogenase } \\
\text { (FAD-GDH) }\end{array}$ & $\begin{array}{l}\text { Poly(methylene green) grafted } \\
\text { on the carbon surface; glassy } \\
\text { carbon electrode }\end{array}$ & $0.196 \mathrm{~cm}^{2}$ & - & $\begin{array}{l}\text { Cyclic voltammetry measurements } \\
\text { using poly(phenothiazine)-modified } \\
\text { GC electrodes as working electrodes } \\
\text { were carried out in a } 0.1 \mathrm{M} \\
\text { phosphate buffer between }-300 \text { and } \\
600 \mathrm{mV} \text { at a scan rate of } 10 \mathrm{mV} / \mathrm{s} \text { in } \\
\text { the presence and absence of } 0.1 \mathrm{M} \\
\text { glucose and } 1.0 \mu \mathrm{MFAD}-\mathrm{GDH} ; \\
\text { response time in } 10 \% \text { using five } \\
\text { different electrodes }\end{array}$ & $\begin{array}{c}3 \mathrm{~mA} / \mathrm{cm}^{2} \text { of glucose } \\
\text { oxidation current }\end{array}$ & [53] \\
\hline $\begin{array}{l}\text { Glucose oxidase } \\
\text { (GOx) }\end{array}$ & $\begin{array}{c}\text { GOx nanocapsule with } \\
\text { SFAD-containing polymeric } \\
\text { network (n(GOx-SFAD-PAM)) }\end{array}$ & - & $\begin{array}{c}\text { Stored at room temperature; } \\
\mathrm{n}(\mathrm{GOx}-\mathrm{SFAD}-\mathrm{PAM}) \text { retained most } \\
\text { activity at } 60 \text { and } 70{ }^{\circ} \mathrm{C} \text {, retaining } \\
\text { more than one third of activity at } \\
80{ }^{\circ} \mathrm{C} \text {; at pH } 3.0 \mathrm{n}(\mathrm{GOx}-\mathrm{SFAD}-\mathrm{PAM}) \\
\text { retained activity } 70.3 \% ; 30 \text {-day } \\
\text { storage at room temperature } \\
\mathrm{n}(\mathrm{GOx}-\mathrm{SFAD}-\mathrm{PAM}) \text { still } \\
\text { maintained } 90 \%\end{array}$ & Response time in $3 \sim 5 \mathrm{~s}$ & $\begin{array}{l}\text { Low detection potential }(-0.4 \\
\text { vs. } \mathrm{Ag} / \mathrm{AgCl}) \text {, high sensitivity } \\
\left(64.97 \mu \mathrm{A} \mathrm{mM} \mathrm{m}^{-1} \mathrm{~cm}^{-2}\right) \text {; high } \\
\text { maximum power density } \\
\left(1011.21 \mu \mathrm{W} / \mathrm{cm}^{2}\right)\end{array}$ & {$[54]$} \\
\hline $\begin{array}{l}\text { Glucose oxidase; } \\
\text { bilirubin oxidase }\end{array}$ & $\begin{array}{l}\text { Copolymer poly(methyl } \\
\text { methacrylate-co- } \\
\text { vinylferrocene) }\end{array}$ & $\begin{array}{c}\text { Gold } \\
(\text { diameter }=2 \mathrm{~mm})\end{array}$ & $\begin{array}{c}\text { The peak currents were the same up } \\
\text { to } 38 \text { cycles, declined only about } \\
7 \mu \mathrm{A} \text { at the last } 12 \text { cycles }\end{array}$ & $\begin{array}{l}\text { The aerated } 100 \mathrm{mM}, \mathrm{pH} 7.4 \\
\text { phosphate buffer; }-1 \text { and }+1 \mathrm{~V}\end{array}$ & $\begin{array}{l}\text { Power density of } 323 \mu \mathrm{W} / \mathrm{cm}^{2} \\
\text { at } 10 \mathrm{mM} \text { glucose at } 0.4 \mathrm{~V}\end{array}$ & [55] \\
\hline $\begin{array}{l}\text { Glucose oxidase } \\
\text { (GOx) }\end{array}$ & $\begin{array}{c}\text { rGO-PEI/Naph- } \\
\text { SH/AgNWs/Frt/Gox }\end{array}$ & $\begin{array}{l}3 \text { mm diameter } \\
\text { glassy carbon } \\
\text { electrode (GCE) }\end{array}$ & Stored at $4{ }^{\circ} \mathrm{C}$ & $\begin{array}{l}\text { Limiting glucose concentration of } \\
50 \mathrm{mM} \text { in PBS (pH 7.0) as } \\
\text { supporting electrolyte at a scan rate } \\
\text { of } 100 \mathrm{mV} / \mathrm{s}\end{array}$ & $\begin{array}{l}\text { Maximum current density } \\
19.9 \mathrm{~mA} / \mathrm{cm}^{2}\end{array}$ & [56] \\
\hline $\begin{array}{l}\text { Glucose oxidase } \\
\text { (GOD) }\end{array}$ & $\begin{array}{l}\text { Matrix of reduced graphene } \\
\text { oxides (RGOs), } \\
\text { polyethylenimine (PEI), and } \\
\text { ferrocene carboxylic acid } \\
\text { (FCCOOH) on carbon } \\
\text { paper (CP) }\end{array}$ & $1.0 \times 5.0 \mathrm{~cm}^{2}$ & $\begin{array}{l}\text { Stored at } 4{ }^{\circ} \mathrm{C} \text {; the bioelectrodes } \\
\text { maintained comparable activity } \\
\text { with the freshly prepared electrode } \\
\text { after two days' storage; the activity } \\
\text { decreased by } 28 \% \text {, while the } \\
\text { noncatalytic current density } \\
\text { dropped slightly after } \\
\text { one-week's storage }\end{array}$ & $\begin{array}{l}\text { GOD-graphene electrode in } 20 \mathrm{mM} \\
\text { PBS with pH ranging from } 5.3 \text { to } 8.1\end{array}$ & $\begin{array}{c}\text { Maximum power density of } \\
5.1 \mu \mathrm{W} / \mathrm{cm}^{2} \text { and an open } \\
\text { circuit voltage of } 0.40 \mathrm{~V} \\
\text { at } 25^{\circ} \mathrm{C}\end{array}$ & [59] \\
\hline
\end{tabular}


Table 1. Cont.

\begin{tabular}{|c|c|c|c|c|c|c|}
\hline Enzyme & Electrode Materials & Electrode Size & $\begin{array}{l}\text { Storage Conditions/ } \\
\text { Lifetime/Stability }\end{array}$ & $\begin{array}{l}\text { Working Conditions/Response } \\
\text { Time/Measurement Range }\end{array}$ & Performance & Ref \\
\hline $\begin{array}{l}\text { FAD-dependent } \\
\text { glucose } \\
\text { dehydrogenase }\end{array}$ & $\begin{array}{l}\text { Porous gold electrodes; } \\
\text { platinum nanoclusters }\end{array}$ & $\begin{array}{c}\text { Au electrodes } \\
\text { (3 mm in diameter) }\end{array}$ & Stored $2 \mathrm{~h}$ at $4{ }^{\circ} \mathrm{C}$ & $\begin{array}{l}0.1 \mathrm{M} \text { phosphate buffer }(\mathrm{pH} 7.0) \text { at } \\
25 \mathrm{C} \text { under quiescent conditions in } \\
\text { an Ar atmosphere at } \mathrm{v}=10 \mathrm{mV} \mathrm{s} 1\end{array}$ & $\begin{array}{l}\text { Current density with PtNCs } \\
\left(\sim 1 \mathrm{~mA} \mathrm{~cm}{ }^{2} \text { at } 0 \mathrm{~V} \text { vs. }\right. \\
\mathrm{Ag}|\mathrm{AgCl}| \text { sat. } \mathrm{KCl}) \text { was } \\
\text { considerably higher than that } \\
\text { without PtNCs }\end{array}$ & [60] \\
\hline $\begin{array}{l}\text { Glucose oxidase } \\
\text { (GOD) }\end{array}$ & $\begin{array}{c}\mathrm{ZnO} \text { nanoparticles decorated } \\
\text { on polyindole-functionalized } \\
\text { MCNTs; ferritin }\end{array}$ & $\begin{array}{l}\text { Glassy carbon } \\
\text { electrode }(\mathrm{GCE}) \text { of } \\
\text { diameter } 3 \mathrm{~mm}\end{array}$ & Stored at $4{ }^{\circ} \mathrm{C}$ & $\begin{array}{l}50 \mathrm{mM} \text { glucose concentration in } \\
\text { phosphate-buffered saline (PBS) } \\
\text { (pH 7.4) as the testing solution by } \\
\text { applying } 100 \mathrm{mV} / \mathrm{s} \text { scan rates }\end{array}$ & $\begin{array}{l}\text { Maximum current density of } \\
4.9 \mathrm{~mA} / \mathrm{cm}^{2}\end{array}$ & [61] \\
\hline $\begin{array}{l}\text { PQQ-glucose } \\
\text { dehydrogenase } \\
\quad(\mathrm{GDH})\end{array}$ & $\begin{array}{c}\text { Carbon nanotube; } \\
\text { multi-walled carbon } \\
\text { nanotubes (MWCNT); pyrene } \\
\text { butyric acid } \\
\text { N-hydroxysuccinimide ester, } \\
\text { and then } \\
\text { N-(5-amino-1-carboxypentyl) } \\
\text { iminodiacetic acid (AB-NTA) } \\
\text { and NiCl2 were added to } \\
\text { modify the NTA-Ni2+ } \\
\text { complex on the CNT surface }\end{array}$ & $\begin{array}{l}\text { Gold (geometrical } \\
\text { area: } 0.02 \mathrm{~cm}^{2} \text { ) }\end{array}$ & - & $\begin{array}{l}\text { Anode cell, } 0.1 \mathrm{M} \text { HEPES buffer, } \\
\text { pH 7.5, was used as an electrolyte } \\
\text { along with } 20 \mathrm{mM} \text { D-glucose }\end{array}$ & Power density $32 \mu \mathrm{W} / \mathrm{cm}^{2}$ & [62] \\
\hline $\begin{array}{l}\text { Glucose oxidase } \\
\text { (GOD) }\end{array}$ & $\begin{array}{l}\text { Cross-linked chitosan/TPP } \\
\text { matrices with } \mathrm{Na}^{\circledR} \text { polymers; } \\
\text { carbon cloth }(\mathrm{CC})\end{array}$ & $\begin{array}{c}\mathrm{CC}\left(3 \times 2 \mathrm{~cm}^{2}\right. \\
131.5 \mathrm{mg})\end{array}$ & $\begin{array}{l}\text { Retained } 89.2 \% \text { of its beginning } \\
\text { performance after } 240 \mathrm{~h} \text { testing }\end{array}$ & $0.1 \mathrm{M} \mathrm{PBS}(\mathrm{pH} 7)$ at $100 \mathrm{mV} / \mathrm{s}$ & $\begin{array}{c}\text { Higher peak power density } \\
\left(1.077 \mathrm{~mW} / \mathrm{cm}^{2}\right) \text { than that } \\
\text { utilizing GOx[CS/TPP]CC } \\
\left(0.776 \mathrm{~mW} / \mathrm{cm}^{2}\right) \text { and } \\
\text { GOx }[\mathrm{CS} / \mathrm{Na}] \mathrm{CC} \\
\left(0.682 \mathrm{~mW} / \mathrm{cm}^{2}\right)\end{array}$ & [63] \\
\hline $\begin{array}{l}\text { Glucose oxidase } \\
\text { (GOD) }\end{array}$ & $\begin{array}{c}\text { Chitosan (CHI)-reduced } \\
\text { graphene (rGO) polyaniline } \\
\text { (PAni)/ ferritin (Frt)/glucose } \\
\text { oxidase (GOx) }\end{array}$ & $\begin{array}{l}\text { Glassy carbon }(\mathrm{GC}) \\
\text { electrode with } \\
0.07 \mathrm{~cm}^{2} \\
\text { surface area }\end{array}$ & $\begin{array}{l}\text { Stored at } 6{ }^{\circ} \mathrm{C} \text {; better storage } \\
\text { stability after one week and it } \\
\text { retained } 95 \% \text { of its initial } \\
\text { current response }\end{array}$ & $\begin{array}{c}0.1 \mathrm{M} \text { PBS of } \mathrm{pH} 7.0 \text { at a sweep rate } \\
\text { of } 100 \mathrm{mV} / \mathrm{s}\end{array}$ & $\begin{array}{l}\text { A stable current response of } \\
3.5 \pm 0.02 \mathrm{~mA} / \mathrm{cm}^{2} \text { in } 20 \mathrm{mM} \\
\text { glucose. The coverage of } \\
\text { enzyme on } 0.07 \mathrm{~cm}^{2} \text { area of } \\
\text { electrode modified with } \\
\text { CHI@rGO-PAni/Frt was } \\
\text { calculated to be } \\
3.80 \times 10^{-8} \mathrm{~mol} / \mathrm{cm}^{2}\end{array}$ & [64] \\
\hline
\end{tabular}


Table 1. Cont.

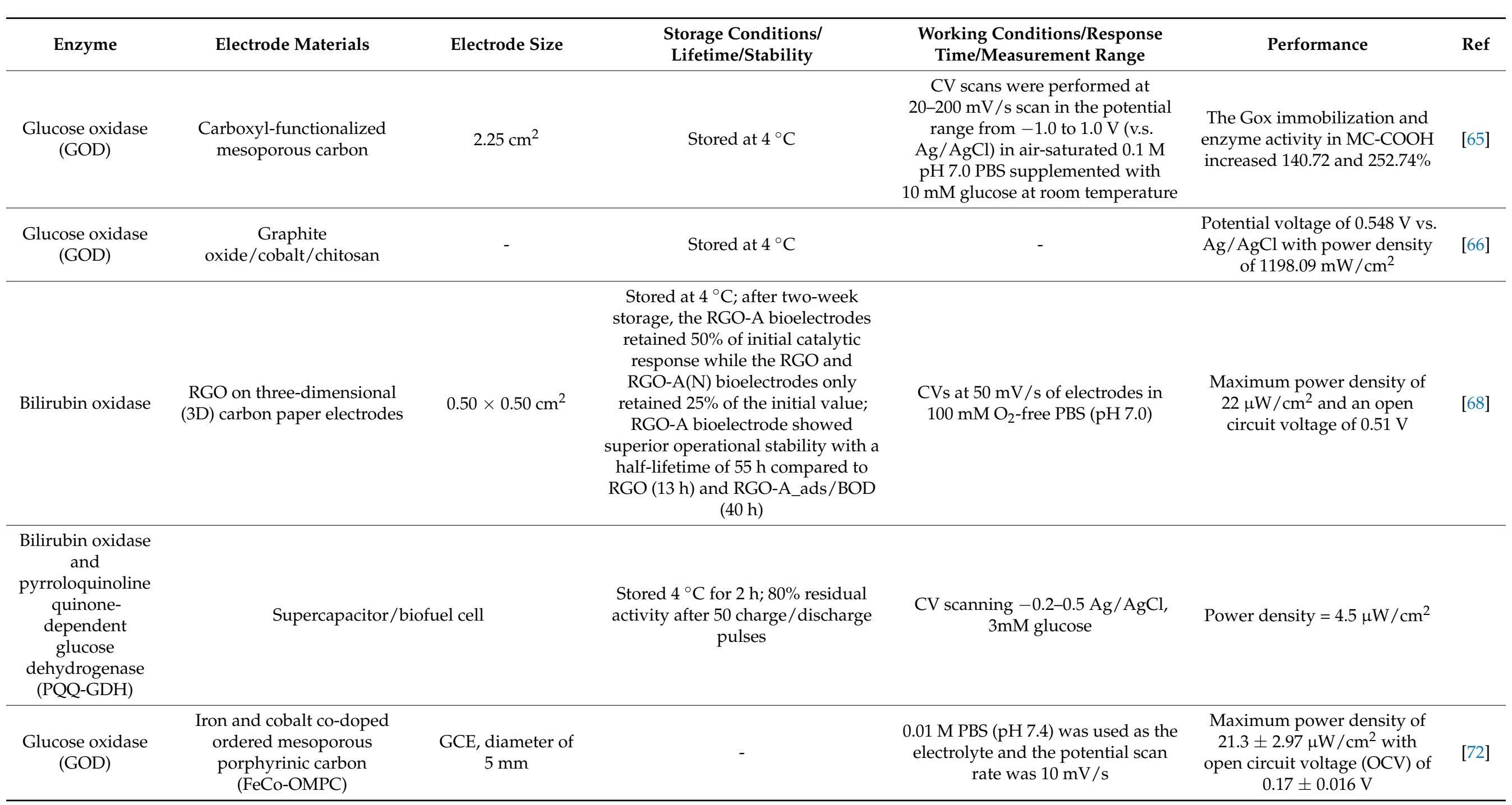


Table 1. Cont.

\begin{tabular}{|c|c|c|c|c|c|c|}
\hline Enzyme & Electrode Materials & Electrode Size & $\begin{array}{l}\text { Storage Conditions/ } \\
\text { Lifetime/Stability }\end{array}$ & $\begin{array}{l}\text { Working Conditions/Response } \\
\text { Time/Measurement Range }\end{array}$ & Performance & Ref \\
\hline $\begin{array}{l}\text { Glucose oxidase } \\
\text { (GOD) }\end{array}$ & RGO/AuNPs/PNR & $1 \times 15 \mathrm{~mm}^{2}$ & Retained activity in $2 \mathrm{~h}$ & $\begin{array}{c}25^{\circ} \mathrm{C} \text { and } 50 \mathrm{uL} / \mathrm{min} \text { of serum } \\
\text { stream flows }\end{array}$ & $\begin{array}{l}\text { Open circuit voltage }(\mathrm{OCV}) \\
\text { and maximum power density } \\
=0.2 \mathrm{~V} \text { and } 3.6 \mu \mathrm{W} / \mathrm{cm}^{2} \text { at a } \\
\text { flow rate of } 50 \mathrm{uL} / \mathrm{min}\end{array}$ & [73] \\
\hline $\begin{array}{l}\text { Glucose oxidase } \\
\text { (GOD) }\end{array}$ & $\begin{array}{l}\text { Gold nanoparticle-modified } \\
\text { carbon nanotube hybrid fibers }\end{array}$ & - & $\begin{array}{l}\text { Operating stability }(\sim 85 \% \text { of the } \\
\text { initial power performance after } \\
15 \text { days })\end{array}$ & $\begin{array}{l}50 \mathrm{~mL} \text { PBS solution }\left(20 \mathrm{mmol} \mathrm{L}^{-1}\right. \\
\text { phosphate, } 0.14 \mathrm{~mol} / \mathrm{L} \mathrm{NaCl}, \mathrm{pH} \text { : } \\
\sim 7.4) \text { at } 37^{\circ} \mathrm{C}\end{array}$ & $\begin{array}{l}\text { Power output of } 1.2 \mu \mathrm{W} / \mathrm{cm}^{2} \\
\text { under a fixed external } \\
\text { resistance (cyclic voltammetry } \\
\text { measurement } \sim 2.1 \mathrm{~mW} / \mathrm{cm}^{2} \text { ) } \\
\text { at } 300 \mathrm{mmol} / \mathrm{L} \text { glucose }\end{array}$ & [72] \\
\hline $\begin{array}{c}\text { Invertase, } \\
\text { mutarotase, } \\
\text { flavine adenine } \\
\text { dinucleotide } \\
\text { (FAD)- } \\
\text { dependent } \\
\text { glucose } \\
\text { dehydrogenase } \\
\text { and fructose } \\
\text { dehydrogenase }\end{array}$ & $\begin{array}{c}\text { Gold } \\
\text { nanoparticles-covalently } \\
\text { bound naphthoquinone } \\
\text { moieties- } \\
\text { cellulose/polypyrrole (CPPy) } \\
\text { paper }\end{array}$ & - & - & $\begin{array}{c}\text { McIlvaine buffer, } \mathrm{pH} 5.5 \text { at a scan } \\
\text { rate of } 1 \mathrm{mV} / \mathrm{s}\end{array}$ & $\begin{array}{l}\text { Power density }= \\
0.81 \mathrm{~mW} / \mathrm{cm}^{2}\end{array}$ & {$[75]$} \\
\hline Bilirubin oxidase & $\begin{array}{c}\text { Prussian blue }(\mathrm{PB}) / \text { russian } \\
\text { white }(\mathrm{PW}) \text {; carbon nanotubes }\end{array}$ & - & - & $\begin{array}{l}\text { Electrolyte solution was } 0.1 \mathrm{M} \text { PBS } \\
(0.1 \mathrm{M}, \mathrm{pH}=6.5) \text { with } 2 \mathrm{mM} \\
\text { NAD+/NADH and } 5 \mathrm{mM} \text { glucose }\end{array}$ & $\begin{array}{l}\text { The EOCV decreased while } \\
\text { the color of the mediated } \\
\text { electrode would return back } \\
\text { to blue }\end{array}$ & [76] \\
\hline Glucose oxidase & $\begin{array}{l}\text { Carbon cloth with Prussian } \\
\text { blue (PB) nanoparticle }\end{array}$ & $\begin{array}{l}\text { Single electrode } \\
\text { sizing of } 1 \mathrm{~cm}^{2}\end{array}$ & $4^{\circ} \mathrm{C}$ and $24 \mathrm{~h}$ & $\begin{array}{l}0.1 \mathrm{M} \text { acetate buffer solution (mixed } \\
\text { solution of acetic acid and sodium } \\
\text { acetate) at } \mathrm{pH} 5 \text { and GOD } \\
\text { concentrations }(6 \mathrm{mg} / \mathrm{mL})\end{array}$ & $\begin{array}{l}5 \text { stacks produced a maximal } \\
\text { power of } 13 \mathrm{~W} \text { with an output } \\
\text { voltage of } 0.88 \mathrm{~V} \text { when load } \\
\text { resistance was } 40 \mathrm{~kW}\end{array}$ & [77] \\
\hline
\end{tabular}




\section{System in EBFC}

Various EBFC systems have been designed for the suitability of EBFC applications. Making the EBFC system is essential for the application involved. For example, to detect blood glucose, the EBFC system developed should be easy to use and dispose of [77]. Most EBFC systems exhibit decreased power and limited lifetime because solvent evaporation in the hydrostatic electrolyte and biofuel depletion require paper exchange replacement and electrolyte refilling [77]. To reduce external components such as pumps, Duong et al. [17] have produced self-pumping EBFCs, as shown in Figure 7. Most fuel cell systems try to minimize the use of external components because it increases the weight of the fuel cell. In addition, the EBFC system that uses a self-pumping technique is suitable for miniaturization applications, where it is ideal for use in portable, wearable, and implantable devices [23]. To produce the self-pumping EBFC system, the flow field produced is driven by the capillary effect, as shown in Figure 7, to supply the fuel, increase efficient mass transfer [75], and reduce fabrication cost and volume of microfluidic biofuel cell [78]. Duong et al. [63] further investigate the factor of electrode microstructure, electrochemical property, and enzyme loading using a self-pumping EBFC that can retain $89.2 \%$ on the stability test for $240 \mathrm{~h}$. Rewatkar et al. [51] also developed a self-pumping EBFC but using the Y-shaped flow structured cell. Meanwhile, Mazar et al. [73] created a Y-shaped flow structured cell using the printed circuit board (PCB)/double-sided pressure-sensitive adhesive (PSA) method to fabricate the cell. The authors also stated that this method is more accessible than using the thermal- or plasma-coating method and photolithography. This Y-shaped microchannel provides an advantage in reducing the depletion boundary layer and cross-diffusional mixing between fuel and oxidant [79].

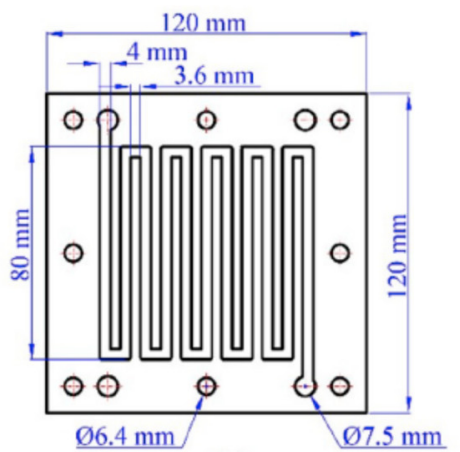

(a)

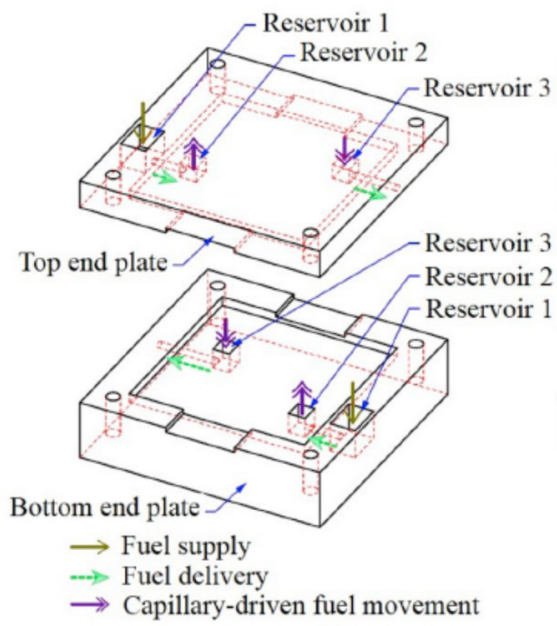

(c)

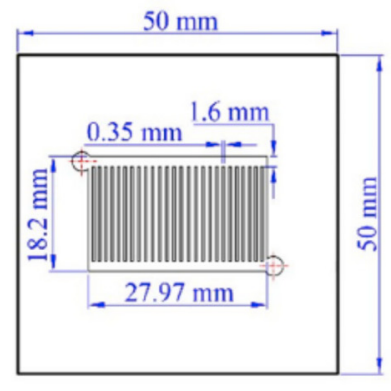

(b)

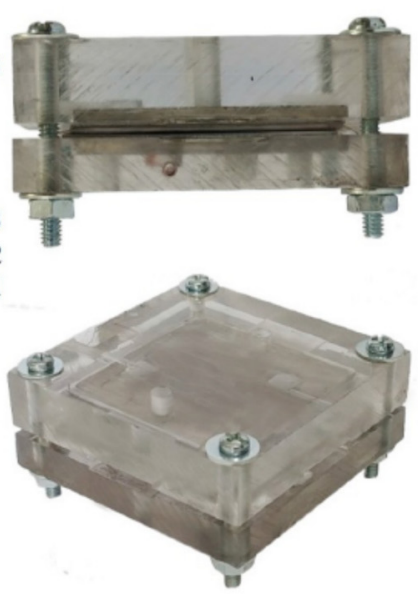

(d)

Figure 7. The design of flow channel plates for (a) typical EBFC (with pump) and (b) self-pumping EBFC (without pump); (c) schematic diagram of top and bottom end plates in the self-pumping EBFC stack and (d) photograph of self-pumping EBFC assembly [17]. Copyright 2019 Elsevier. 
Several researchers have developed microfluidic EBFCs [73,80-82] without using the proton exchange membrane (PEM). Although this system successfully eliminates the use of expensive PEM, problems such as poor mass transport, mixing between fuel and oxidant, high internal resistance, insufficient fuel utilization, and interactive interference still occur [83]. Poor mass transport occurs when reactant/glucose slowly reaches the enzyme for the catalytic to happen. The system of microfluidic EBFC with cross-diffusional mixing was developed by Khan et al. [79]. This study examined the differences in flow rates and microchannel heights that lead to the optimal output of power density and current density at $153 \mu \mathrm{W} / \mathrm{cm}^{2}$ and $450 \mu \mathrm{A} / \mathrm{cm}^{2}$ at a flow rate of $25 \mathrm{~mL} / \mathrm{h}$ and microchannel height of $450 \mu \mathrm{m}$, respectively. Gai et al. [83] introduced the nanocarrier in a membrane-less EBFC metal-organic framework $\left[\left[\mathrm{Fe}(\mathrm{CN})_{6}\right]_{3}\right]^{3-}$ to reduce the internal resistance in EBFC and enhance the power output 700 times. The ability of the enzyme to have high stability and selectivity is essential in EBFC. Therefore, the need to analyze the product resulting in the reaction at the EBFC electrode is needed. Varničić et al. [84] produced membrane-less EBFCs and used nuclear magnetic resonance spectroscopy to determine the production of two main products: D-arabinose and formic acid. The authors found that the production of this product was influenced by the enzyme selection on the cathode side of EBFC.

Needle-type EBFCs have also been developed to detect glucose by poking the needle on the skin. Two types of microneedles that have been used are polymeric needles and metallic hollow needles. Yin et al. [85] used needle-type EBFC to detect the glucose in apple, grape, and kiwifruit and gave the EBFC a value of 33,55 , and $44 \mu \mathrm{W}$, respectively. The resulting system had anti-biofouling 2-methacryloyloxyethyl phosphorylcholine (MPC) polymer and waterproof tape at the cathodic chamber to maintain power output and lifetime EBFC.

To expedite and facilitate EBFC cell fabrication with high precision and uniformity [40], 3D printing was used by Rewatkar et al. [81] due to the quick fabrication process, costeffectiveness, and simplicity. In this study, polylactic acid and conductive composite graphene materials were used to form microchannels and electrodes. The power and current of the EBFC produced using this fabrication are $4.15 \mu \mathrm{W} / \mathrm{cm}^{2}$ and $13.36 \mu \mathrm{A} / \mathrm{cm}^{2}$ at different flow rates, respectively. In other work by the same research group [80], they used non-toxic pencil graphite electrodes (PGE) as electrode materials in the 3D printing fabrication process. MWCNT coats the PGE as support for enzyme immobilization. The microchannel used in this study was a Y-shaped type that produced $18 \mu \mathrm{W} / \mathrm{cm}^{2}$ at $0.433 \mathrm{~V}$. The fabrication methods used in making EBFC are fused deposition modeling (FDM), paper-based, photolithography, laser micromachining, soft lithography, and xurography. Although various fabrication techniques can be chosen, advantages such as simple processing procedure, cost-efficiency, speedy production, high security, and durability are given priority [40].

Stacking fuel cells combine several cells to increase power. Yoshida et al. [86] combined six EBFC cells in series, as shown in Figure 8, and used fructose as fuel. This, combined with a very thin electrode suitable for the skin patch, increased the voltage and current by $1.5 \mathrm{~V}$ and $80 \mu \mathrm{A}$, respectively. Shitanda et al. [87] also combined six cells, but shapes such as hexagons were fabricated using screen printing. These cells were used to detect glucose in the urine, and the detectable glucose concentration was in the range of 1 to $25 \mathrm{mM}$. It seems that the fabrication of these two stacks shows that EBFC is easy to dispose of after use. Markovic et al. [88] also used the screen printing technique to produce a single cell of EBFC. Rewatkar et al. [78] developed the four series-parallel arrangements (series, parallel, and combined series-parallel) of microfluidic paper-based analytical EBFCs using a mini 3D-printed platform. In this study, the 4-series arrangement produced a stable open-circuit voltage of $1.65 \mathrm{~V}$ with a power density of $46.4 \mu \mathrm{W} / \mathrm{cm}^{2}$ at $0.8 \mathrm{~V}$. The feedforward control of the DC-DC PWM (pulse width modulation) boost converter was used in the power management circuit for stacking EBFC so that the power generated had a high power conversion efficiency. Seok et al. [77] studied the effect of EBFC power when changing the number and size of cells to optimize the DC output voltage. The efficiency of the DC-DC 
converter of $50 \%$ produced a capacity of $13 \mu \mathrm{W}$ with an output voltage of $0.88 \mathrm{~V}$ on five stacks of EBFC.

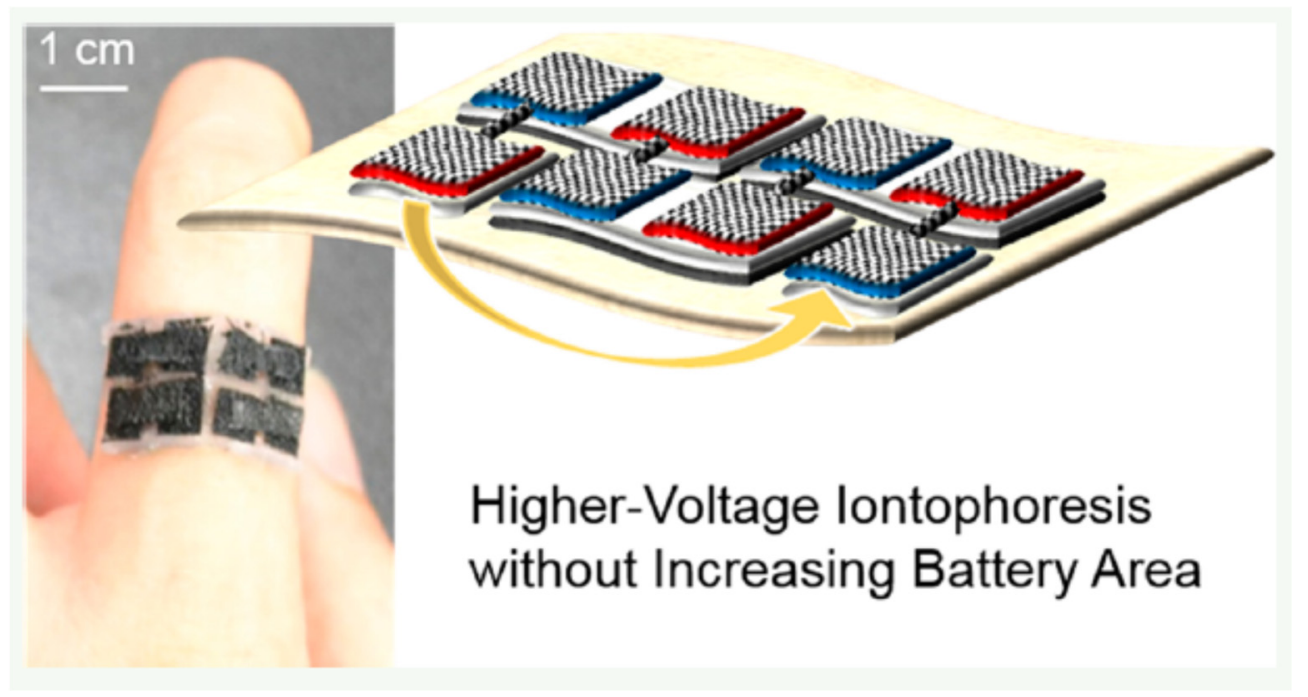

Figure 8. The series connection of EBFC [86]. Copyright 2020 ACS Publication.

\section{Conclusions}

EBFC has advantages over other fuel cells, such as non-toxic chemical fuel, simplicity, low cost, small size, easy disposal, rapid start-up, eco-friendliness, anti-interference performance, and being easy to operate at room temperature and at neutral $\mathrm{pH}$. However, the electrode materials used must have characteristics such as biocatalytic properties, biocompatibility, biodegradability, implantability, and mechanical flexibility in EBFC. Enzymes that become the heart of the EBFC need to immobilize on the surface electrode. Various methods such as polymer conduction, crosslinking, layer-by-layer assembly, and covalent attachment are used. The current trend mainly uses polymer conduction and crosslinking methods to immobilize the enzyme where the interaction between this material and the enzyme needs to be seen in terms of storage, solvent, $\mathrm{pH}$, and thermal stability, function well, and have high efficiency. However, there is still inadequate and ineffective interaction between the materials used for enzyme immobilization, including imperfect and low enzyme loading, leaching out of enzyme that leads to degradation in long-term operation, potential enzyme poisoning when using non-biocompatibility support materials, reduced lifetime, and limited enzyme stability. Recent studies also use nanoparticle materials to increase electron transfer, although mediators are still used and have higher power performance in EBFCs. However, the mediator also has problems, such as the mediator itself being toxic in the EBFC environment, leakage, producing a low open-circuit voltage (OCV), mediator mobilization, high cost, and instability of the metal ion-based redox. Meanwhile, EBFC systems have various types depending on the use or application of EBFC, such as developing a self-pumping technique suitable for miniaturization applications, while the needle-type EBFCs have been designed to detect glucose poking the needle on the skin. The development of EBFC requires 3D printers due to the quick fabrication process, cost-effectiveness, and simplicity. Therefore, overall, among the combinations of materials that can be studied, namely nanoparticles, graphene, and conductive polymers, these three have the advantage of chemical stability and enhanced electron transfer, and the interaction between these materials can improve EBFC performance. The development of chitosan selection in EBFC is also prevalent in publications because chitosan has the advantages of sensitivity, selectivity, stability, and reproducibility.

Author Contributions: Writing-original draft preparation, N.A.K.; funding acquisition, H.Y. All authors have read and agreed to the published version of the manuscript. 
Funding: The authors gratefully acknowledge financial support by the Ministry of Education under FRGS/1/2019/TK02/UKM/02/4. The authors also gratefully acknowledge financial support for this work funded by the Ministry of Science and Technology of Taiwan, grant number MOST-109-2221E-005-004, and also partially supported by the Ministry of Education of Taiwan under the Higher Education Sprout Project and Southbound Scheme Program.

Institutional Review Board Statement: Not Applicable.

Informed Consent Statement: Not Applicable.

Data Availability Statement: Data sharing is not applicable to this article as no new data were created or analyzed in this study.

Acknowledgments: The help of the crew of Micro/Nano Machining Laboratory, including Fu-Wei Wang, Hun-Ting Tao, Shui-Rei Wang, and Hsuan-Hung Yu, with experimental works is appreciated.

Conflicts of Interest: The authors declare no conflict of interest.

\section{References}

1. Shakeel, N.; Ahmad, A.; Ahamed, M.I.; Asiri, A.M. Kraton based polymeric nanocomposite bioanode for the application in a biofuel cell. Enzym. Microb. Technol. 2019, 127, 43-49. [CrossRef] [PubMed]

2. Arjun, A.M.; Vimal, M.; Sandhyarani, N. A hybrid hydrogel separated biofuel cell with a novel enzymatic anode and glucose tolerant cathode. Int. J. Hydrog. Energy 2019, 44, 27056-27066. [CrossRef]

3. Li, X.; Li, D.; Zhang, Y.; Lv, P.; Feng, Q.; Wei, Q. Encapsulation of enzyme by metal-organic framework for single-enzymatic biofuel cell-based self-powered biosensor. Nano Energy 2020, 68, 104308. [CrossRef]

4. Southcott, M.; MacVittie, K.; Halámek, J.; Halámková, L.; Jemison, W.D.; Lobel, R.; Katz, E. A pacemaker powered by an implantable biofuel cell operating under conditions mimicking the human blood circulatory system-Battery not included. Phys. Chem. Chem. Phys. 2013, 15, 6278-6283. [CrossRef] [PubMed]

5. Xiao, X.; McGourty, K.D.; Magner, E. Enzymatic biofuel cells for self-powered, controlled drug release. J. Am. Chem. Soc. 2020, 142, 11602-11609. [CrossRef]

6. Jeon, W.-Y.; Lee, J.-H.; Dashnyam, K.; Choi, Y.-B.; Kim, T.-H.; Lee, H.-H.; Kim, H.-W.; Kim, H.-H. Performance of a glu-cose-reactive enzyme-based biofuel cell system for biomedical applications. Sci. Rep. 2019, 9, 10872. [CrossRef]

7. Li, X.; Lv, P.; Yao, Y.; Feng, Q.; Mensah, A.; Li, D.; Wei, Q. A novel single-enzymatic biofuel cell based on highly flexible conductive bacterial cellulose electrode utilizing pollutants as fuel. Chem. Eng. J. 2020, 379, 122316. [CrossRef]

8. Kumar, A.; Sharma, S.; Pandey, L.M.; Chandra, P. Nanoengineered material based biosensing electrodes for enzymatic biofuel cells applications. Mater. Sci. Energy Technol. 2018, 1, 38-48. [CrossRef]

9. Kwon, C.H.; Ko, Y.; Shin, D.; Kwon, M.; Park, J.; Bae, W.K.; Lee, S.W.; Cho, J. High-power hybrid biofuel cells using layer-by-layer assembled glucose oxidase-coated metallic cotton fibers. Nat. Commun. 2018, 9, 4479. [CrossRef]

10. Franco, J.H.; Klunder, K.J.; Lee, J.; Russell, V.; de Andrade, A.R.; Minteer, S.D. Enhanced electrochemical oxidation of ethanol using a hybrid catalyst cascade architecture containing pyrene-tempo, oxalate decarboxylase and carboxylated multi-walled carbon nanotube. Biosens. Bioelectron. 2020, 154, 112077. [CrossRef] [PubMed]

11. Zhang, L.; Zhou, M.; Wen, D.; Bai, L.; Lou, B.; Dong, S. Small-size biofuel cell on paper. Biosens. Bioelectron. 2012, 35, 155-159. [CrossRef]

12. Wang, Y.; Wang, F.; Han, Z.; Huang, K.; Wang, X.; Liu, Z.; Wang, S.; Lu, Y. Construction of sandwiched self-powered biosensor based on smart nanostructure and capacitor: Toward multiple signal amplification for thrombin detection. Sens. Actuators $B$ Chem. 2020, 304, 127418. [CrossRef]

13. Wang, F.-T.; Wang, Y.-H.; Xu, J.; Huang, K.-J. A high-energy sandwich-type self-powered biosensor based on DNA bioconjugates and a nitrogen doped ultra-thin carbon shell. J. Mater. Chem. B 2020, 8, 1389-1395. [CrossRef] [PubMed]

14. Tominaga, M.; Kuwahara, K.; Tsushida, M.; Shida, K. Cellulose nanofiber-based electrode as a component of an enzyme-catalyzed biofuel cell. RSC Adv. 2020, 10, 22120-22125. [CrossRef]

15. Shakeel, N.; Ahamed, M.I.; Ahmed, A.; Rahman, M.M.; Asiri, A.M. Functionalized magnetic nanoparticle-reduced graphene oxide nanocomposite for enzymatic biofuel cell applications. Int. J. Hydrog. Energy 2019, 44, 28294-28304. [CrossRef]

16. Alamry, K.A. Application of electrically conducting nanocomposite material polythiophene@nio/frt/gox as anode for enzymatic biofuel cells. Materials 2020, 13, 1823.

17. Duong, N.B.; Wang, C.-L.; Huang, L.Z.; Fang, W.T.; Yang, H. Development of a facile and low-cost chitosan-modified carbon cloth for efficient self-pumping enzymatic biofuel cells. J. Power Sources 2019, 429, 111-119. [CrossRef]

18. Jayapiriya, U.S.; Rewatkar, P.; Goel, S. Miniaturized polymeric enzymatic biofuel cell with integrated microfluidic device and enhanced laser ablated bioelectrodes. Int. J. Hydrog. Energy 2021, 46, 3183-3192.

19. Bahar, T.; Yazici, M.S. Assessment of glucose oxidase based enzymatic fuel cells integrated with newly developed chitosan membranes by electrochemical impedance spectroscopy. Electroanalysis 2020, 32, 1304-1314. [CrossRef] 
20. Wang, Y.; Sun, H.; Liu, M.; Lu, H.; Zhao, G. A novel self-powered aptasensor for environmental pollutants detection based on simple and efficient enzymatic biofuel cell. Sens. Actuators B Chem. 2020, 305, 127468. [CrossRef]

21. Shakeel, N.; Ahamed, M.I.; Ahmed, A.; Kanchi, S.; Kashmery, H.A. Hydrothermally synthesized defective nimose2 nanoplates decorated on the surface of functionalized swcnts doped polypyrrole scaffold for enzymatic biofuel cell applications. Int. J. Hydrog. Energy 2021, 46, 3240-3250. [CrossRef]

22. Wang, X.; Kim, J.H.; Choi, Y.B.; Kim, H.-H.; Kim, C.-J. Fabrication of optimally configured layers of swcnts, gold nanoparticles, and glucose oxidase on ito electrodes for high-power enzymatic biofuel cells. Korean J. Chem. Eng. 2019, 36, 1172-1183. [CrossRef]

23. Choi, H.S.; Yang, X.; Kim, D.S.; Yang, J.H.; Han, S.O.; Park, C.; Kim, S.W. Power generation from cheese whey using enzymatic fuel cell. J. Clean. Prod. 2020, 254, 120181. [CrossRef]

24. Chu, T.-F.; Rajendran, R.; Kuznetsova, I.; Wang, G.-J. High-power, non-enzymatic glucose biofuel cell based on a nano/micro hybrid-structured au anode. J. Power Sources 2020, 453, 227844. [CrossRef]

25. Ohayon, D.; Nikiforidis, G.; Savva, A.; Giugni, A.; Wustoni, S.; Palanisamy, T.; Chen, X.; Maria, I.P.; Di Fabrizio, E.; Costa, P.M.F.J.; et al. Biofuel powered glucose detection in bodily fluids with an n-type conjugated polymer. Nat. Mater. 2020, 19, 456-463. [CrossRef] [PubMed]

26. Babadi, A.A.; Wan-Mohtar, W.A.A.Q.I.; Chang, J.-S.; Ilham, Z.; Jamaludin, A.A.; Zamiri, G.; Akbarzadeh, O.; Basirun, W.J. Highperformance enzymatic biofuel cell based on three-dimensional graphene. Int. J. Hydrog. Energy 2019, 44, 30367-30374. [CrossRef]

27. Franco, J.H.; de Almeida, P.Z.; Abdellaoui, S.; Hickey, D.P.; Ciancaglini, P.; de Lourdes, T.M.; Polizeli, M.; Minteer, S.D.; de Andrade, A.R. Bioinspired architecture of a hybrid bifunctional enzymatic/organic electrocatalyst for complete ethanol oxidation. Bioelectrochemistry 2019, 130, 107331. [CrossRef] [PubMed]

28. Hyun, K.; Kang, S.; Kim, J.; Kwon, Y. New biocatalyst including a 4-nitrobenzoic acid mediator embedded by the crosslinking of chitosan and genipin and its use in an energy device. ACS Appl. Mater. Interfaces 2020, 12, 23635-23643. [CrossRef]

29. Munauwarah, R.; Bojang, A.A.; Wu, H.S. Characterization of enzyme immobilized carbon electrode using covalent-entrapment with polypyrrole. J. Chin. Inst. Eng. 2018, 41, 710-719. [CrossRef]

30. Conghaile, P.Ó.; Kumar, R.; Ferrer, M.L.; Leech, D. Glucose oxidation by enzyme electrodes using genipin to crosslink chitosan, glucose oxidase and amine-containing osmium redox complexes. Electrochem. Commun. 2020, 113, 106703. [CrossRef]

31. Zhang, J.; Huang, X.; Zhang, L.; Si, Y.; Guo, S.; Su, H.; Liu, J. Layer-by-layer assembly for immobilizing enzymes in enzymatic biofuel cells. Sustain. Energy Fuels 2020, 4, 68-79. [CrossRef]

32. Miki, K.; Watanabe, T.; Koh, S. Electrochemical characterization of cvd-grown graphene for designing electrode/biomolecule interfaces. Crystals 2020, 10, 241. [CrossRef]

33. Galindo-de-la-Rosa, J.; Álvarez, A.; Gurrola, M.P.; Rodríguez-Morales, J.A.; Oza, G.; Arriaga, L.G.; Ledesma-García, J. Alcohol dehydrogenase immobilized on tio2 nanotubes for ethanol microfluidic fuel cells. ACS Sustain. Chem. Eng. 2020, 8, 10900-10910. [CrossRef]

34. Mohamad, N.R.; Marzuki, N.H.C.; Buang, N.A.; Huyop, F.; Wahab, R.A. An overview of technologies for immobilization of enzymes and surface analysis techniques for immobilized enzymes. Biotechnol. Biotechnol. Equip. 2015, 29, 205-220. [CrossRef] [PubMed]

35. Minteer, S.D.; Atanassov, P.; Luckarift, H.R.; Johnson, G.R. New materials for biological fuel cells. Mater. Today 2012, 15, 166-173. [CrossRef]

36. Lee, J.Y.Y.; Elouarzaki, K.; Sabharwal, H.S.; Fisher, A.C.; Lee, J.-M. A hydrogen/oxygen hybrid biofuel cell comprising an electrocatalytically active nanoflower/laccase-based biocathode. Catal. Sci. Technol. 2020, 10, 6235-6243. [CrossRef]

37. Sakthivel, M.; Ramaraj, S.; Chen, S.-M.; Chen, T.-W.; Ho, K.-C. Transition-metal-doped molybdenum diselenides with defects and abundant active sites for efficient performances of enzymatic biofuel cell and supercapacitor applications. ACS Appl. Mater. Interfaces 2019, 11, 18483-18493. [CrossRef]

38. Ma, C.; Wu, R.; Huang, R.; Jiang, W.; You, C.; Zhu, L.; Zhu, Z. Directed evolution of a 6-phosphogluconate dehydrogenase for operating an enzymatic fuel cell at lowered anodic phs. J. Electroanal. Chem. 2019, 851, 113444. [CrossRef]

39. Kang, Z.; Job Zhang, Y.-H.P.; Zhu, Z. A shriveled rectangular carbon tube with the concave surface for high-performance enzymatic glucose/o2 biofuel cells. Biosens. Bioelectron. 2019, 132, 76-83. [CrossRef]

40. Jayapiriya, U.S.; Goel, S. Surface modified 3d printed carbon bioelectrodes for glucose/o2 enzymatic biofuel cell: Comparison and optimization. Sustain. Energy Technol. Assess. 2020, 42, 100811.

41. Ji, J.; Ro, S.; Kwon, Y. Membraneless biofuel cells using new cathodic catalyst including hemin bonded with amine functionalized carbon nanotube and glucose oxidase sandwiched by poly(dimethyl-diallylammonium chloride). J. Ind. Eng. Chem. 2020, 87, 242-249. [CrossRef]

42. Díaz-González, J.-c.M.; Escalona-Villalpando, R.A.; Arriaga, L.G.; Minteer, S.D.; Casanova-Moreno, J.R. Effects of the cross-linker on the performance and stability of enzymatic electrocatalytic films of glucose oxidase and dimethylferrocene-modified linear poly(ethyleneimine). Electrochim. Acta 2020, 337, 135782. [CrossRef]

43. Ji, J.; Woo, J.; Chung, Y.; Joo, S.H.; Kwon, Y. Dual catalytic functions of biomimetic, atomically dispersed iron-nitrogen doped carbon catalysts for efficient enzymatic biofuel cells. Chem. Eng. J. 2020, 381, 122679. [CrossRef]

44. Niiyama, A.; Murata, K.; Shigemori, Y.; Zebda, A.; Tsujimura, S. High-performance enzymatic biofuel cell based on flexible carbon cloth modified with mgo-templated porous carbon. J. Power Sources 2019, 427, 49-55. [CrossRef] 
45. Tang, J.; Werchmeister, R.M.L.; Preda, L.; Huang, W.; Zheng, Z.; Leimkühler, S.; Wollenberger, U.; Xiao, X.; Engelbrekt, C.; Ulstrup, J.; et al. Three-dimensional sulfite oxidase bioanodes based on graphene functionalized carbon paper for sulfite/o2 biofuel cells. ACS Catal. 2019, 9, 6543-6554. [CrossRef]

46. Trifonov, A.; Stemmer, A.; Tel-Vered, R. Power generation by selective self-assembly of biocatalysts. ACS Nano 2019, 13, 8630-8638. [CrossRef] [PubMed]

47. Fritea, L.; Gross, A.J.; Reuillard, B.; Gorgy, K.; Cosnier, S.; Le Goff, A. A diethyleneglycol-pyrene-modified ru(ii) catalyst for the design of buckypaper bioelectrodes and the wiring of glucose dehydrogenases. ChemElectroChem 2019, 6, 3621-3626. [CrossRef]

48. Shen, F.; Pankratov, D.; Halder, A.; Xiao, X.; Toscano, M.D.; Zhang, J.; Ulstrup, J.; Gorton, L.; Chi, Q. Two-dimensional graphene paper supported flexible enzymatic fuel cells. Nanoscale Adv. 2019, 1, 2562-2570. [CrossRef]

49. Rocha, I.M.; Soares, O.S.G.P.; Fernandes, D.M.; Freire, C.; Figueiredo, J.L.; Pereira, M.F.R. N-doped carbon nanotubes for the oxygen reduction reaction in alkaline medium: Synergistic relationship between pyridinic and quaternary nitrogen. ChemistrySelect 2016, 1, 2522-2530. [CrossRef]

50. Wan, J.; Mi, L.; Tian, Z.; Li, Q.; Liu, S. A single-liquid miniature biofuel cell with boosting power density via gas diffusion bioelectrodes. J. Mater. Chem. B 2020, 8, 3550-3556. [CrossRef]

51. Rewatkar, P.; Goel, S. Microfluidic paper based membraneless biofuel cell to harvest energy from various beverages. J. Electrochem. Sci. Eng. 2020, 10, 49-54. [CrossRef]

52. Gross, A.J.; Holzinger, M.; Cosnier, S. Buckypaper bioelectrodes: Emerging materials for implantable and wearable biofuel cells. Energy Environ. Sci. 2018, 11, 1670-1687. [CrossRef]

53. Tsuruoka, N.; Soto, S.S.; Tahar, A.B.; Zebda, A.; Tsujimura, S. Mediated electrochemical oxidation of glucose via poly(methylene green) grafted on the carbon surface catalyzed by flavin adenine dinucleotide-dependent glucose dehydrogenase. Colloids Surf. B Biointerfaces 2020, 192, 111065. [CrossRef] [PubMed]

54. Huang, J.; Zhang, Y.; Ding, F.; Chen, D.; Wang, Y.; Jin, X.; Zhu, X. Rational design of electroactive redox enzyme nanocapsules for high-performance biosensors and enzymatic biofuel cell. Biosens. Bioelectron. 2021, 174, 112805. [CrossRef] [PubMed]

55. Korkut, S.; Kiliç, M.S.; Hazer, B. Newly designed bioanode for glucose/o2 biofuel cells to generate renewable energy. Asia-Pac. J. Chem. Eng. 2019, 14, e2374. [CrossRef]

56. Shakeel, N. Optimization of rgo-pei/naph-sh/agnws/frt/gox nanocomposite anode for biofuel cell applications. Sci. Rep. 2020, 10, 8919. [CrossRef]

57. Herkendell, K.; Stemmer, A.; Tel-Vered, R. Magnetically induced enzymatic cascades-Advancing towards multi-fuel direct/mediated bioelectrocatalysis. Nanoscale Adv. 2019, 1, 1686-1692. [CrossRef]

58. Herkendell, K.; Stemmer, A.; Tel-Vered, R. Extending the operational lifetimes of all-direct electron transfer enzymatic biofuel cells by magnetically assembling and exchanging the active biocatalyst layers on stationary electrodes. Nano Res. 2019, 12, 767-775. [CrossRef]

59. Werchmeister, R.M.L.; Tang, J.; Xiao, X.; Wollenberger, U.; Hjuler, H.A.; Ulstrup, J.; Zhang, J. Three-dimensional bioelectrodes utilizing graphene based bioink. J. Electrochem. Soc. 2019, 166, G170-G177. [CrossRef]

60. Adachi, T.; Fujii, T.; Honda, M.; Kitazumi, Y.; Shirai, O.; Kano, K. Direct electron transfer-type bioelectrocatalysis of fad-dependent glucose dehydrogenase using porous gold electrodes and enzymatically implanted platinum nanoclusters. Bioelectrochemistry 2020, 133, 107457. [CrossRef]

61. Shakeel, N.; Ahamed, M.I.; Kanchi, S.; Kashmery, H.A. Green synthesis of zno nanoparticles decorated on polyindole functionalized-mcnts and used as anode material for enzymatic biofuel cell applications. Sci. Rep. 2020, 10, 5052.

62. Sakamoto, H.; Koto, A.; Takamura, E.-I.; Asakawa, H.; Fukuma, T.; Satomura, T.; Suye, S.-I. Development of biofuel cell using a complex of highly oriented immobilized his-tagged enzyme and carbon nanotube surface through a pyrene derivative. J. Nanosci. Nanotechnol. 2019, 19, 3551-3557. [CrossRef]

63. Duong, N.B.; Truong, V.M.; Li, Y.-S.; Wang, C.-L.; Yang, H. Improving the immobilization of glucose oxidase on carbon cloth via a hybrid approach of crosslinked chitosan/tpp matrices with na polymers for high-performance self-pumping enzyme-based biofuel cells. Energy Fuels 2020, 34, 10050-10058. [CrossRef]

64. ul Haque, S.; Nasar, A.; Rahman, M.M. Applications of chitosan (chi)-reduced graphene oxide (rgo)-polyaniline (pani) conducting composite electrode for energy generation in glucose biofuel cell. Sci. Rep. 2020, 10, 10428. [CrossRef]

65. Lv, C.; Li, S.; Liu, L.; Zhu, X.; Yang, X. Enhanced electrochemical characteristics of the glucose oxidase bioelectrode constructed by carboxyl-functionalized mesoporous carbon. Sensors 2020, 20, 3365. [CrossRef] [PubMed]

66. Kim, D.S.; Choi, H.S.; Yang, X.; Yang, J.H.; Lee, J.H.; Yoo, H.Y.; Lee, J.; Park, C.; Kim, S.W. Improvement of power generation of enzyme fuel cell by novel go/co/chitosan electrodeposition. J. Ind. Eng. Chem. 2020, 81, 108-114. [CrossRef]

67. Butsyk, O.; Olejnik, P.; Romero, E.; Plonska-Brzezinska, M.E. Postsynthetic treatment of carbon nano-onions: Surface modification by heteroatoms to enhance their capacitive and electrocatalytic properties. Carbon 2019, 147, 90-104. [CrossRef]

68. Tang, J.; Yan, X.; Huang, W.; Engelbrekt, C.; Duus, J.Ø.; Ulstrup, J.; Xiao, X.; Zhang, J. Bilirubin oxidase oriented on novel type three-dimensional biocathodes with reduced graphene aggregation for biocathode. Biosens. Bioelectron. 2020, 167, 112500. [CrossRef] [PubMed]

69. Kuroishi, K.; Doi, T.; Yonaha, Y.; Kusajima, I.; Nishioka, Y.; Imai, S. Enzymatic biofuel cell using grooved gel of fructose between graphene-coated carbon fiber cloth electrodes. IEICE Trans. Electron. 2019, 102, 151-154. [CrossRef] 
70. Shen, F.; Pankratov, D.; Pankratova, G.; Toscano, M.D.; Zhang, J.; Ulstrup, J.; Chi, Q.; Gorton, L. Supercapacitor/biofuel cell hybrid device employing biomolecules for energy conversion and charge storage. Bioelectrochemistry 2019, 128, 94-99. [CrossRef] [PubMed]

71. Kizling, M.; Dzwonek, M.; Więckowska, A.; Stolarczyk, K.; Bilewicz, R. Biosupercapacitor with an enzymatic cascade at the anode working in a sucrose solution. Biosens. Bioelectron. 2021, 186, 113248. [CrossRef]

72. Ji, J.; Woo, J.; Chung, Y.; Joo, S.H.; Kwon, Y. Membraneless enzymatic biofuel cells using iron and cobalt co-doped ordered mesoporous porphyrinic carbon based catalyst. Appl. Surf. Sci. 2020, 511, 145449. [CrossRef]

73. Mashayekhi Mazar, F.; Alijanianzadeh, M.; Molaei Rad, A.; Heydari, P. Power harvesting from physiological serum in microfluidic enzymatic biofuel cell. Microelectron. Eng. 2020, 219, 111159. [CrossRef]

74. Kwon, C.H.; Ko, Y.; Shin, D.; Lee, S.W.; Cho, J. Highly conductive electrocatalytic gold nanoparticle-assembled carbon fiber electrode for high-performance glucose-based biofuel cells. J. Mater. Chem. A 2019, 7, 13495-13505. [CrossRef]

75. Kizling, M.; Dzwonek, M.; Nowak, A.; Tymecki, Ł.; Stolarczyk, K.; Więckowska, A.; Bilewicz, R. Multi-substrate biofuel cell utilizing glucose, fructose and sucrose as the anode fuels. Nanomaterials 2020, 10, 1534. [CrossRef] [PubMed]

76. Yu, W.; Kong, X.; Gu, C.; Gai, P.; Li, F. Ultrasensitive self-powered biosensors with visual self-checking function for pathogenic bacteria detection. Sens. Actuators B Chem. 2020, 307, 127618. [CrossRef]

77. Seok, S.; Wang, C.; Lefeuvre, E.; Park, J. Autonomous energy harvester based on textile-based enzymatic biofuel cell for on-demand usage. Sensors 2020, 20, 5009. [CrossRef] [PubMed]

78. Rewatkar, P.; U.S., J.; Goel, S. Optimized shelf-stacked paper origami-based glucose biofuel cell with immobilized enzymes and a mediator. ACS Sustain. Chem. Eng. 2020, 8, 12313-12320. [CrossRef]

79. Khan, H.; Kim, C.M.; Kim, S.Y.; Goel, S.; Dwivedi, P.K.; Sharma, A.; Kim, Y.H.; Kim, G.M. Fabrication of enzymatic biofuel cell with electrodes on both sides of microfluidic channel. Int. J. Precis. Eng. Manuf. Green Technol. 2019, 6, 511-520. [CrossRef]

80. Rewatkar, P.; Bandapati, M.; Goel, S. Miniaturized additively manufactured co-laminar microfluidic glucose biofuel cell with optimized grade pencil bioelectrodes. Int. J. Hydrog. Energy 2019, 44, 31434-31444. [CrossRef]

81. Rewatkar, P.; Goel, S. Next-generation 3d printed microfluidic membraneless enzymatic biofuel cell: Cost-effective and rapid approach. IEEE Trans. Electron Devices 2019, 66, 3628-3635. [CrossRef]

82. Rewatkar, P.; Kothuru, A.; Goel, S. Pdms-based microfluidic glucose biofuel cell integrated with optimized laser-induced flexible graphene bioelectrodes. IEEE Trans. Electron Devices 2020, 67, 1832-1838. [CrossRef]

83. Gai, P.; Gu, C.; Kong, X.; Li, F. Anode-driven controlled release of cathodic fuel via ph response for smart enzymatic biofuel cell. iScience 2020, 23, 101133. [CrossRef] [PubMed]

84. Varničić, M.; Zasheva, I.N.; Haak, E.; Sundmacher, K.; Vidaković-Koch, T. Selectivity and sustainability of electroenzymatic process for glucose conversion to gluconic acid. Catalysts 2020, 10, 269. [CrossRef]

85. Yin, S.; Liu, X.; Kobayashi, Y.; Nishina, Y.; Nakagawa, R.; Yanai, R.; Kimura, K.; Miyake, T. A needle-type biofuel cell using enzyme/mediator/carbon nanotube composite fibers for wearable electronics. Biosens. Bioelectron. 2020, 165, 112287. [CrossRef]

86. Yoshida, S.; Mizuno, T.; Kusama, S.; Sato, K.; Raut, B.; Nishizawa, M. Series-connected flexible biobatteries for higher voltage electrical skin patches. ACS Appl. Electron. Mater. 2020, 2, 170-176. [CrossRef]

87. Shitanda, I.; Fujimura, Y.; Nohara, S.; Hoshi, Y.; Itagaki, M.; Tsujimura, S. Paper-based disk-type self-powered glucose biosensor based on screen-printed biofuel cell array. J. Electrochem. Soc. 2019, 166, B1063-B1068. [CrossRef]

88. Marković, N.; Conzuelo, F.; Szczesny, J.; González García, M.B.; Hernández Santos, D.; Ruff, A.; Schuhmann, W. An air-breathing carbon cloth-based screen-printed electrode for applications in enzymatic biofuel cells. Electroanalysis 2019, 31, 217-221. [CrossRef] 